\title{
MicroRNAs: a complex regulatory network drives the acquisition of malignant cell phenotype
}

\author{
Libero Santarpia ${ }^{1,2}$, Milena Nicoloso ${ }^{3}$ and George A Calin ${ }^{3}$
}

\begin{abstract}
'Translational Research Unit, Department of Oncology, Hospital of Prato and Istituto Toscana Tumori, Piazza dell' Ospedale, 59100 Prato, Italy

Departments of ${ }^{2}$ Endocrine Neoplasia and Hormonal Disorders and ${ }^{3}$ Experimental Therapeutics, Unit 36, The University of Texas M. D. Anderson Cancer Center, 1515 Holcombe Boulevard, Houston, Texas 77030, USA

(Correspondence should be addressed to G A Calin; Email: gcalin@mdanderson.org; L Santarpia at Translational Research Unit, Department of Oncology, Hospital of Prato Istituto Toscana Tumori; Email: Isantarp@ mdanderson.org)
\end{abstract}

\begin{abstract}
Several lines of evidence indicate that tumorigenesis is a complex multistep process, and that most, if not all, cancers acquire the same set of functional capabilities during development and progression, albeit through various mechanistic strategies. Increasing data show an important role of microRNAs (miRNAs or miRs) in regulating various aspects of cancer biology. This review describes the role of microRNAs during the multiple steps that drive the progressive transformation of normal cells into highly malignant derivatives, outlining the role of microRNAs in regulating the common hallmarks of tumorigenesis: self-sufficiency in growth signals, insensitivity to antigrowth signals, abnormal apoptosis, limitless replicative potential, induction and sustained angiogenesis, and tissue invasion and metastasis. Recent evidence suggests an important role of microRNAs in the regulation of the expression of most genes regulating and coordinating a wide variety of processes in endocrine glands. We will highlight microRNAs of potential relevance to endocrine tumors and hormone-dependent cancers. Through this overview of how microRNAs regulate multiple targets and entire pathways, we will provide insight into the potential to develop new molecular microRNA-targeted therapies for endocrine tumors.
\end{abstract}

Endocrine-Related Cancer (2010) 17 F51-F75

\section{miRs and gene regulation}

MicroRNAs (miRNAs or miRs) are a small (20-23 nucleotides), highly conserved noncoding class of regulatory RNA molecules expressed in a tissue- and development-specific manner (Ambros 2008). miRs are excised from a long nucleotide primary hairpin precursor RNA structure (pre-miR). The pre-miR sequence is transcribed from a larger Pol II primary transcript (pri-miR), whereas miRs are generated by a coordinated sequential processing of a long primary form into smaller miR sequences by the Drosha (in

This paper is one of 6 papers that form part of a special Focus Section on microRNAs. The Guest Editors for this section were Professor Alfredo Fusco, Naples, Italy, and Professor Carlo M Croce, Columbus, $\mathrm{OH}$, USA. the nucleus) and Dicer (in the cytoplasm) RNase III endonucleases and are incorporated into the RNAinduced silencing complex (Kim 2005; Fig. 1). These molecules modulate the expression of protein-coding genes by binding to complementary sequences of target mRNA transcripts. Most miRs bind to the $3^{\prime}$ untranslated region (UTR) of the RNA transcript, but binding to coding or nontranslated $5^{\prime}$ sequences can occur as well (Rigoutsos 2009). Perfect complementarity of miRs to target sequences leads to transcriptional repression by cleaving and degrading the mRNA transcripts. In cellular biology, miRs have the important role of reinforcing molecular networks that otherwise would be affected by random variations in gene expression. As key players in canalizing genetic programs and stabilizing developmental pathways 


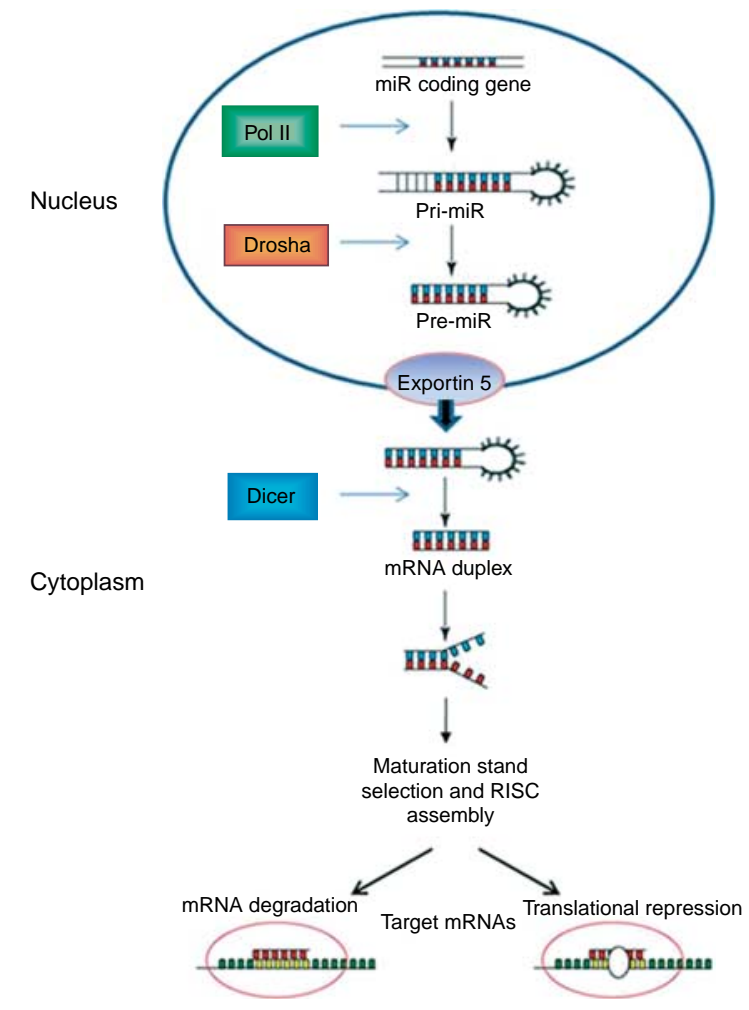

Figure 1 The pre-miR sequence is transcribed from a larger $\mathrm{Pol}$ II primary transcript (pri-miR), whereas miRs are generated by a coordinated sequential processing of a long primary form into smaller miR sequences by the Drosha (in the nucleus) and Dicer RNase (in the cytoplasm) III endonucleases and are incorporated into the RNA-induced silencing complex (RISC), which recognizes its multiple substrates. According to the degree of miR-mRNA complementarity, the silencing mechanism is based on the inhibition of protein translation or mRNA degradation, with a common final effect, which is a reduction of total protein expression levels.

(Hornstein \& Shomron 2006), miRs minimize the noise of loose transcription regulation (Coller et al. 2007). This is particularly relevant in the processes of lineage commitment and cell cycle regulation, where the high extent of specific gene transcription requires fine-tuning at the translational level. Interestingly, it is now becoming clear that complex regulatory networks between miRs and their gene targets are actually common mechanisms that have evolved in mammals that enhance the robustness of gene regulation (Tsang et al. 2007).

\section{Mechanisms of miR deregulation}

Usually, miRs are located at cancer-associated genomic regions; however, the differential expression of miRs in malignant cells versus normal cells - and sometimes within the same tumor cell - is a complex phenomenon, which could be explained by the complex regulation of miRs by oncogenes, tumor suppressor genes, epigenetic mechanisms, and genomic abnormalities (Calin et al. 2004, Calin \& Croce 2006). Accordingly, studies have identified abnormalities of miRs in human cancers, revealing their transcriptional regulators (Chang et al. 2007, He et al. 2007). Cancer-associated miRs have been located downstream of major oncogenes and tumor suppressors that act as transcription factors. Similarly, transcription factors governing metastatic gene expression programs have also been found to control miRs involved in metastasis (Nicoloso et al. 2009). Additionally, a recent study examining epigenetic change in miR genes in tumors identified a miR hypermethylation signature characteristic of human metastasis (Lujambio et al. 2008). Understanding the causes of miR deregulation during the metastatic process continues to evolve; other mechanisms could be involved in this process, such as abnormal processing of precursor miRs to mature molecules and deletion or amplification because of the location of miRs in cancer-associated genomic regions.

\section{miRs as powerful master regulators of cancer}

Increasing evidence supports the supposition that miRs play an important role in different types of cancers and in various aspects of cancer biology (Nicoloso et al. 2009, Spizzo et al. 2009). Expression of miRs and the role of miRs in cancer are tissue- and tumor-specific. Abnormal miR levels in tumors have important pathogenetic consequences: miRs may act as oncogenes or suppressor genes. miRs overexpressed in tumors downregulate tumor suppressor genes, whereas miRs lost by tumors participate in oncogene overexpression. Recent evidence supports the ability of miRs to regulate several steps during neoplastic cell transformation. Many aspects of tumorigenesis, also defined as a hallmark of cancer (Hanahan \& Weinberg 2000), are common to almost all, if not all, tumors: 1) self-sufficiency of tumor cells, 2) insensitivity to antigrowth signals, 3) abnormal apoptosis, 4) limitless replicative potential, 5) induction and sustained angiogenesis, and 6) invasion and metastasis. The latter is a crucial factor responsible for a worse prognosis and outcome for cancer patients. Recent data support the idea that numerous aspects of the metastatic process are also regulated by miRs. To give origin to cancer and to spread, or metastasize, a tumor cell must complete a complex set of processes, including transformation, enhanced cell motility, tissue 
invasion, intravasation, dissemination, extravasation, and, finally, colonization to distant organs. However, the mechanism underlying the hallmarks of cancer and the molecular pathways underlying each of the aforementioned steps are still not well elucidated. In light of new perspectives on the role of miRs in malignant cell transformation, we will try to elucidate the significance and power of miRs in the tumorigenic process, focusing on the capabilities a cell must acquire to fulfill the malignant program with particular attention to the miRs most commonly implicated in endocrine tumors. Figure 2 shows important miR functions in neoplastic cell transformation.

\section{Self-sufficiency in growth signals}

Normal cell division is regulated by stimulatory and inhibitory growth signals. These signals are transmitted to the cells by transmembrane receptors that have tyrosine kinase activity. Growth signaling involves interaction of diffusible growth factors or cytokines with transmembrane receptors as well as regulation of growth by components of the surrounding environment, extracellular matrix (ECM), and cell-cell interaction. Extracellular signals received by the tyrosine kinase receptors (TKRs) are translated into a variety of different cellular responses by a cascade of signal transductions. Malignant cells acquire the capability to escape from the tight dependency from extracellular growth signals.

The constitutive activation of TKRs, such as human epidermal growth receptor $2 / 3$ (HER2/3), epidermal growth factor receptor (EGFR), vascular endothelial growth factor receptor (VEGFR), plateletderived growth factor receptor (PDGFR), and c-Met, is commonly observed in several endocrine disorders (Heaney \& Melmed 2005).

Some miRs have been shown to overcome the selfsufficiency in growth signaling leading to abnormal cell proliferation. The HER members (EGFR, HER2/ERRB2, and HER3) belong to a growth factor-TKR family diffusely deregulated in tumors (Moasser 2007). A recent study demonstrated that miR-205 is downmodulated in breast tumors, directly targets HER 3 receptors, and inhibits activation of the downstream mediator Akt (Iorio et al. 2009). The reintroduction of $m i R-205$ in $\mathrm{SKBr} 3$ cells inhibits their clonogenic potential and restores a potent proapoptotic activity (Iorio et al. 2009). Another recent study showed that the cognate ERRB2 receptor can regulate the expression of $m i R-21$ via the mitogen-activated protein kinase and extracellular signal-regulated kinase $1 / 2($ ERK1/2) pathway in breast cancer cell lines, and that $m i R-21$, in turn, was able to regulate the expression of programmed cell death-4 (PDCD4), thus revealing a new mechanism for HER2/neu-induced cancer cell proliferation via miR deregulation (Huang et al. 2009). The ERBB2 TKR is also frequently overexpressed in prostate cancer, and it is associated with disease progression and poor survival. $m i R-331$ is decreased in prostate cancer, and it targets two specific sites within the ERBB2 mRNA $3^{\prime}$ UTR. Transfection of multiple prostate cancer cell lines with $m i R-331$ showed a reduction of ERBB2 mRNA and protein expression and a block of the downstream phosphatidylinositol 3-kinase (PI3K)/Akt signaling pathway (Epis et al. 2009).

Reduction of $m i R-125 a$ and $m i R-125 b$ expression levels has been reported in breast, ovarian, and prostate cancers (Iorio et al. 2005, 2007, Ozen et al. 2007). $m i R-125 a$ and $m i R-125 b$ have been proven to directly repress ERBB2/3 and to shut down the downstream phosphorylation of ERK1/2 and Akt; therefore, loss of $m i R-125 a$ and $125 b$ favors the constitutive activation of the ERBB prosurvival pathway (Scott et al. 2007). Another study showed that one relevant target of $m i R-210$ in hypoxia was the surface receptor Ephrin-A3 (Fasanaro et al. 2008). miR-210 was necessary and sufficient to downmodulate Ephrin-A3 expression, thereby modulating endothelial cell response to hypoxia, cell survival, migration, and differentiation (Fasanaro et al. 2008).

EGFR, also called HER1 in humans, is a surface receptor that belongs to the ErbB family of receptors and is frequently mutated or overexpressed in cancer. $m i R-7$ plays a critical role in the downregulation of EGFR mRNA and protein expression in different cancer cell lines (breast, lung, and glioblastoma), inducing cell cycle arrest and cell death. $m i R-7$ has also been shown to attenuate the activation of protein kinase B (Akt) and ERK 1/2, which are two critical effectors of the EGFR signaling (Webster et al. 2009).

A recent study on PDGFR signaling in organogenesis showed that its correct expression and function depend on miR-140-directed regulation (Eberhart et al. 2008). PDGFR is known to be an important tumorigenic factor in ovarian cancer (Apte et al. 2004, Iorio et al. 2007), and miR-140 was among the most significantly downregulated miRs in ovarian cancer (Iorio et al. 2007). Finally, three miRs $m i R-34 b, m i R-34 c$, and $m i R-199 a$ have been shown to regulate MET receptor expression. Inhibition of these endogenous miRs resulted in increased expression of MET proteins, whereas their exogenous expression in cancer cells blocked MET-induced signal transduction (Migliore et al. 2008). 


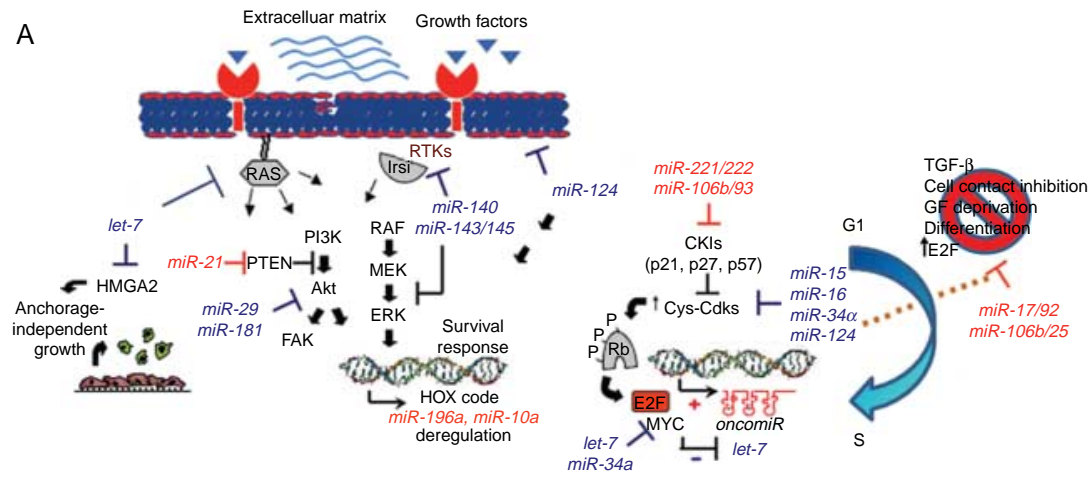

Self-sufficiency
in growth
signals

Insensitivity

to

antigrowth signals
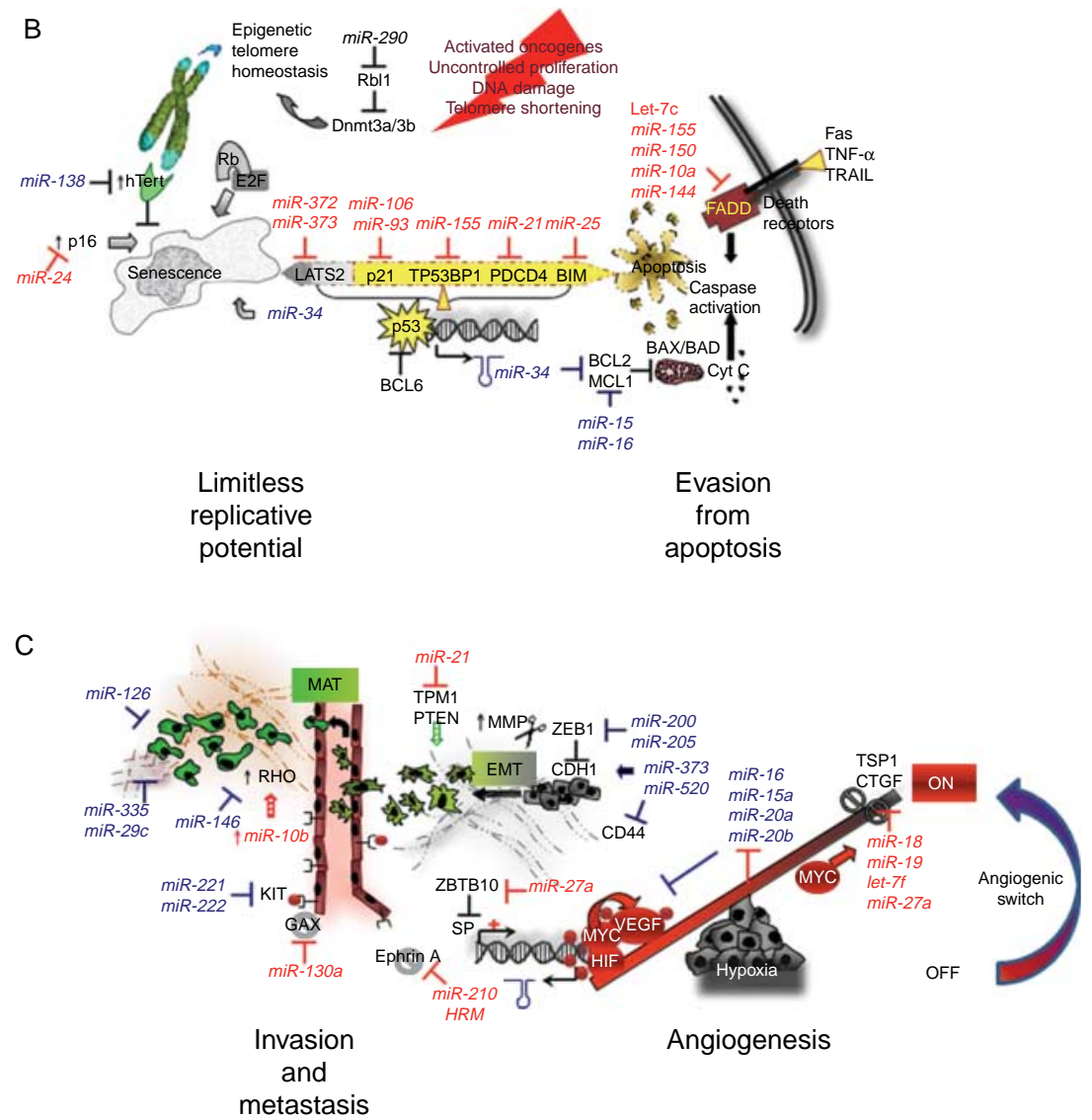

Figure 2 miRs are important regulators of gene programs involved in all the hallmarks of cancer including: (A) self-sufficiency in growth signals and insensitivity to antigrowth signals, (B) limitless replicative potential and abnormal apoptosis, (C) tissue invasion and metastasis and induction of and sustained angiogenesis.

RAS activation is a common means by which tumor cells escape growth factor dependency and become oncogene addicted. Let-7, one of the first miRs identified, has now become a well-documented posttranscriptional regulator of RAS (Johnson et al.
2005). The relevance of this mechanism has been shown by an inverse correlation between let-7 and RAS expression levels (Johnson et al. 2005), and more recently, by demonstration that therapeutic approaches targeting let-7 in lung cancer models can determine 
tumor regression by affecting cell proliferation (Esquela-Kerscher et al. 2008, Kumar et al. 2008).

There are many more mitogen-kindled pathways constitutively activated by tumor cells, and for many of these, the miR regulatory functions are rapidly coming to light. $m i R-143$ and $m i R-145$ are two clustered miRs on chromosome $5 \mathrm{q}$ that are commonly downregulated in different tumor types, such as tumors of the colon, breast, and ovary (Michael et al. 2003, Iorio et al. 2005, 2007, Akao et al. 2007, Chen et al. 2009). Their loss has been shown to accelerate cell proliferation by deregulation of the ERK5 signaling pathway since they directly target ERK5 mRNA (Akao et al. 2006). Interestingly, $m i R-145$, in addition to acting on ERK5, has recently been shown to exert its antiproliferative effects on colon cancer tumor cells by suppressing insulin receptor substrate (IRS1) expression levels (Shi et al. 2007). IRS1, a docking protein for the insulin-like growth factor type 1 receptor (IGF1R) and insulin receptor, sends mitogenic, antiapoptotic, and antidifferentiation signals to the cell as part of a pivotal oncogenic pathway exploited by several types of tumor cells. miR-143 has recently been shown to regulate a member of the RAS family, KRAS in the Lovo colorectal cell line; the cells that were treated with a miR-143 inhibitor showed a stimulated cell proliferation, whereas $m i R-143$ overexpression had an opposite effect. Finally, inhibition of KRAS expression by miR-143 inhibited constitutive phosphorylation of ERK1/2. Taken together, these data are evidence that $m i R-143$ is significant in suppressing colorectal cancer cell growth through inhibition of KRAS translation (Chen et al. 2009).

PI3K-Akt intracellular survival signaling is a switch diffusely turned on by tumor cells to allow malignant progression. At different levels of this pathway, miRs step in; for example, overexpression of $m i R-21$ and $m i R-214$ is responsible for PTEN repression (Yang et al. 2008) and consequent loss of Akt-negative regulation. Another study showed that differential expression of PTEN-targeting miR-19a and miR-21 modulates PTEN protein levels and Cowden syndrome phenotypes, irrespective of the patient's mutation status, which is evidence of their roles as genetic modifiers (Pezzolesi et al. 2008). Another study showed a ubiquitous loss of miR-126 expression in colon cancer cell lines (Guo et al. 2008a). Restoration of $m i R-126$ in these cancer cells induced a reduction in $\mathrm{p} 85-\beta$ protein levels, which is an important regulatory subunit involved in stabilizing and propagating the PI3K signal (Guo et al. 2008a).
Normal cells perceive contact with the ECM component as a major prosurvival signal; therefore, modulation of malignant cell interactions with the tumor microenvironment becomes a prerequisite for tumor self-sufficiency in growth signals (Guo et al. 2006). $m i R-124$, an epigenetically silenced $\mathrm{miR}$ in glioblastomas, breast cancers, and lung cancers (Lujambio \& Esteller 2007, Silber et al. 2008), is very likely to be an important player in this process; in fact, it has been shown to regulate the integrin- $\beta-1$ subunit and laminin- $\gamma-1$ expression (Cao et al. 2007). Specifically in glioblastomas, $m i R-124$, together with miR-137, was shown to contribute to tumor cell selfrenewing potential by turning off the neuronal differentiation switch (Silber et al. 2008).

The self-sufficiency of tumor cells is also due to their ability to grow in an anchorage-independent manner, and they do not undergo apoptosis following detachment from the basal membrane (a process also termed anoikis). This quality can be achieved by downmodulation of let-7 (Mayr et al. 2007), among other mechanisms, which facilitates anchorage-independent growth. This effect has been linked to de-repression of the pleiotropic architectural transcription factor HMGA2, a major let-7 target (Lee \& Dutta 2007), serving multiple differentiation programs. In addition, tumor cells support themselves by diverting bystander cells to support their proliferative needs; in line with this requirement, the oncogenic $m i R-155$, overexpressed in a wide variety of tumors (Volinia et al. 2006), is induced in macrophages by the JNK pathway and by numerous inflammatory mediators (O'Connell et al. 2007), underscoring the link between inflammation and cancer.

\section{Insensitivity to antigrowth signals}

Growth inhibitory signals received by transmembrane cell surface receptors coupled to intracellular signals cause cells to enter into quiescence or a differentiated postmitotic state; both conditions require an arrest of and withdrawal from the cell cycle. Cancer cells evade these mechanisms, becoming insensitive to antigrowth signals. Specifically, this circuit, which enables cells to respond to antigrowth signals, is associated with components governing the transit of the cells through the $G_{1}$ phase of the cell cycle. Almost all antiproliferative signals are controlled by $\mathrm{pRb}$ and its subunits (RBb1/105, p107, and $\mathrm{Rb} 2 / \mathrm{p} 130$ ); these, in turn, sequester E2F transcription factors repressing the expression of genes required for cell cycle progression (Iaquinta \& Lees 2007). Disruption of the Rb pathway unlocks E2Fs and allows cell proliferation. 
Although E2F transcription factors are prevalently superintended by the tumor suppressor $\mathrm{Rb}$ through sequestration, their expression levels are also relevant and have been illustrated to be controlled at the posttranscriptional level by a series of miRs. These belong to two highly conserved miR families, which are grouped in distinct genomic clusters - the miR-17-92 cluster on chromosome $13 \mathrm{q} 31.1$ and the miR-106b-25 cluster on chromosome 7q22.1. Specifically, miR-20a inhibits E2F2 and E2F3 (Sylvestre et al. 2007), whereas miR-17-5p, miR-20a, miR-106b, and miR-92 inhibit E2F1 (O'Donnell et al. 2005, Petrocca et al. 2008). Furthermore, E2F-activating transcription factors have recently been shown to regulate the expression of these clustered miRs (O'Donnell et al. 2005, Woods et al. 2007, Petrocca et al. 2008). Unbound E2Fs increase $m i R-17-92$ and $m i R-106 b-25$ expression, and in turn, these keep E2F levels in check and participate in the delicate equilibrium between cell proliferation and apoptosis, which is affected by alteration of E2F levels. Additionally, the miR-17-92 cluster preferentially shuts down the proapoptotic E2F1 in favor of the proliferative E2F3 transcriptional network. Upregulated miRs from these clusters are specifically able to target apoptotic and growth inhibitory proteins, such as p21, PTEN, and BIM (Petrocca et al. 2008). Furthermore, the so-called oncomiR-17-92 has been shown to be directly transactivated by MYC (O'Donnell et al. 2005) and to cooperate in tumorigenesis (He et al. 2005a). Similar to MYC, the miR-17-92 cluster appears to be essential for integrating signals from the environment into the $G_{1}$ phase of the cell cycle and determining whether a signal should be interpreted as proliferative or apoptotic (Coller et al. 2007). Under physiological conditions, the $m i R-17-92$ cluster avoids an excessive MYC activation, dampening the E2F positive feedback loop and ensuring the correct timing of E2F accumulation at the end of the $G_{1}$ phase of the cell cycle.

Table 1 Important deregulated microRNAs in endocrine tumors

Deregulated microRNAs

\begin{tabular}{|c|c|c|}
\hline \multirow{2}{*}{ Endocrine tumors $^{a}$} & & \\
\hline & Downregulated & Upregulated \\
\hline Breast cancers & $\begin{array}{l}\text { Let-7 family, miR-9 family (associated with vascular } \\
\text { invasion and lymph node metastases), miR-10b, } \\
\text { miR-17-92 }{ }^{\mathrm{b}}, \mathrm{miR}-29 \text { family, miR-101, miR-124 } \\
\text { familyc }^{\mathrm{c}}, \mathrm{miR} 125 \mathrm{a} / \mathrm{b}, \mathrm{miR}-126, \mathrm{miR}-143 / \mathrm{miR}-145 \\
\text { cluster } m i R-200 \text { family }^{\mathrm{d}}, \text { miR-206 (associated to } \\
\text { relapse), miR-335 (during the metastatic } \\
\text { progression) }\end{array}$ & $\begin{array}{l}\text { miR-10b (in metastatic tumors), miR-17-5p (breast } \\
\text { cancer cell lines), miR-21, miR-27 (MDA-MB-231 } \\
\text { cells), miR-29b-2, miR-146, miR-155, miR-181 } \\
\text { family, miR-373 and miR-520c (in metastatic } \\
\text { tumors) }\end{array}$ \\
\hline Prostate cancers & $\begin{array}{l}\text { Let-7 family, } \mathrm{miR}-15 \mathrm{a} / \mathrm{miR}-16-1 \text { cluster, } \mathrm{miR}-101 \text {, } \\
\text { miR-125a/b, miR-146a, miR-205, miR-221 } \\
\text { (aggressive and metastatic tumors), miR-449 }\end{array}$ & miR-21, miR-106b-93-25 cluster, miR-181 family \\
\hline Ovarian cancers & $\begin{array}{l}\text { Let-7 family, miR-9, miR-15-16, miR-17-92 } \\
\quad \text { miR-29a/b, miR-34, miR-105, miR125a/b, } \\
\text { miR-140, miR-145, miR-199a, miR-200 family }\end{array}$ & $m i R-21, m i R-30 b / d, m i R-181 b, \operatorname{miR}-203, m i R-373$ \\
\hline Liver cancers & $\begin{array}{l}\text { miR-1, miR-23b, miR-26a, miR-34a, miR-101, } \\
\text { miR-122a (in tumor with poor prognosis), let-7, } \\
\text { miR-141, miR-199a }\end{array}$ & miR-21, miR-122a, miR-221/222 \\
\hline $\begin{array}{l}\text { Pancreas and } \\
\text { gastric cancers }\end{array}$ & $\begin{array}{l}\text { Let-7 family, miR-15a/miR-16-1 cluster; Let-7 } \\
\text { family, miR-31, miR-141, miR-143/miR145, } \\
\text { miR-451 }\end{array}$ & $\begin{array}{l}\text { miR-155, miR-181 family, miR196a, miR-217; } \\
\text { miR-21, miR-29b-2, miR-106b-93-25 cluster, } \\
\text { miR-128b miR-191, miR-223 }\end{array}$ \\
\hline Thyroid cancers & $\begin{array}{l}\text { pre-miR-146a (SNP-rs2910164), miR-26a, } \\
\quad \text { miR-30a-5p, miR-30d, miR-125b, miR-138 }\end{array}$ & $\begin{array}{l}\text { miR-17-92, miR-21, miR-106a/b, miR-146b, } \\
\quad \text { miR-181b, mR-192, miR-197, miR-221, miR-222, } \\
\text { miR-328, miR-346 }\end{array}$ \\
\hline Adrenal cancers & $m i R-9, m i R-34 a, m i R-125 a / b, m i R-214, m i R-511$ & $\begin{array}{l}\text { miR-17-92 cluster, miR-184, miR-221, miR-449 } \\
\text { (hyperplasia), miR-503 }\end{array}$ \\
\hline Pituitary tumors & $\begin{array}{l}\text { Let-7 family, miR-15a/miR-16-1 cluster, miR-21, } \\
\text { miR-141, mR-143, miR-145, mR-150 }\end{array}$ & \\
\hline
\end{tabular}

\footnotetext{
${ }^{\mathrm{a} A l l}$ tumor histotypes.

bLoss of heterozygosity.

cHypermethylation.

${ }^{\mathrm{d} D o w n r e g u l a t e d ~ i n ~ m e t a s t a t i c ~ b r e a s t ~ c a n c e r s . ~}$

eDifferent studies reported dissimilar miRs expression levels (see text for further details).
} 
In tumors with MYC activation, miR-17-92 cluster upregulation overcomes protective MYC-induced apoptotic E2F responses, leading to uncontrolled cellular proliferation. The oncomiR-17-92 is upregulated in several tumors (Table 1). Deregulated expression of MYC, which renders tumor cells nonresponsive to external antigrowth signals, is among the most common abnormalities in human malignancies, and miRs have been proven to contribute directly to MYC deregulation. Through the transcriptional repression of let-7a, MYC initiates a positive feedback loop that sustains high MYC expression; in fact, let-7a is competent to repress MYC (Sampson et al. 2007, Kim et al. 2009). Additionally, miR-34a, a commonly downregulated miR in cancers, also targets MYC and participates in its abnormal expression in tumors (Wei et al. 2008).

Several epithelial malignancies are characterized by insensitivity of cells to the homeostatic effect of transforming growth factor- $\beta$ (TGF- $\beta$; Heldin et al. 2009, Wu \& Hill 2009). The TGF- $\beta$ pathway can be altered in tumor cells by downregulation or mutations in the TGF- $\beta$ receptor, loss of Smad signaling flow from the cytoplasm to the nucleus, or mutations in growth arrest effector genes (e.g. p $27^{\mathrm{KIP} 1}, \mathrm{p} 21^{\mathrm{CIP} 1}$, $\mathrm{p} 16^{\mathrm{INK} 4 \mathrm{a}}$, and $\mathrm{p} 15^{\mathrm{INK} 4 \mathrm{~b}}$ ). Impaired TGF- $\beta$ signaling occurs in several neoplasms where cell cycle checkpoints activated following growth arrest stimuli may be suppressed by activation of MDM2 and cyclindependent protein kinase-4 (CDK4) or by overexpression of cyclin D1, a $\mathrm{G}_{1}$ phase sensor for growth factors that promotes entry into the cell cycle. It has been recently shown that cyclin D1 upregulation may be due to truncation of its $3^{\prime}$ UTR, which renders it insensitive to miR-16 downmodulation (Chen et al. 2008), which is well known to regulate transcripts involved in cell cycle progression (Linsley et al. 2007). Another crucial cell cycle gatekeeper to which tumor cells can become insensitive is the cyclin-dependent kinase inhibitor (CKI) p27 ${ }^{\mathrm{KIP} 1}$, the expression of which is frequently lost in cancers (Chu et al. 2008). $m i R-221$ and $m i R-222$, two miRs found to be upregulated in many tumors such as papillary thyroid carcinomas (PTCs), hepatocarcinomas, and glioblastomas, directly target $\mathrm{p} 27^{\mathrm{KIP} 1}$, providing cells an additional tool to avoid cell cycle arrest (le Sage et al. 2007, Visone et al. 2007a, Fornari et al. 2008). $m i R-221$ and $m i R-222$ are also able to downregulate the related CKI $\mathrm{p} 57^{\mathrm{KIP} 2}$, preventing quiescence and favoring S-phase entry (Fornari et al. 2008).

Similarly, the CKI p $21^{\mathrm{CIP} 1}$, which is downstream of both TGF- $\beta$ and DNA damage-induced growth arrest pathways, is repressed by miRs upregulated in tumors from the miR-106b-25 cluster (Petrocca et al. 2008). Cell cycle arrest in response to DNA damage is an important antitumorigenic mechanism.

The miR-15a/miR-16, located at chromosome $13 \mathrm{q} 14$, are frequently deleted or downregulated in different types of tumors, in particular, squamous cell carcinomas and adenocarcinomas of the lung where the expression of $m i R-15 \mathrm{a} / \mathrm{miR}-16$ is inversely correlated with the expression of cyclin D1. In nonsmall cell lung cancer (NSCLC) cell lines, cyclins D1, D2, and E1 are physiologically regulated by $m i R-15 a / m i R-16$. Consistent with these results, overexpression of these miRs induces cell cycle arrest in $G(1)-G(0)$. Interestingly, $\mathrm{H} 2009$ cells lacking $\mathrm{Rb}$ are resistant to $m i R$-15a/miR-16-induced cell cycle arrest, whereas reintroduction of functional $\mathrm{Rb}$ resensitizes these cells to miR activity. In contrast, downregulation of $\mathrm{Rb}$ in A549 cells by RNA interference confers resistance to these miRs. Thus, these miRs play an important role in inducing cell cycle arrest in an Rb-dependent manner. These data confirm that $\mathrm{G}(1)$ cyclins are major targets of $m i R-15 a / m i R-16$ in NSCLC, contributing to cell cycle control and partially implicated in the tumorigenesis of NSCLC (Bandi et al. 2009).

A few miRs, such as $m i R-34 a$, were recently shown to play key regulatory roles in cell cycle progression. $m i R-34 a$ is induced in response to p53 activation and mediates $G_{1}$ arrest by downregulating multiple cell cycle-related transcripts. $m i R-34 a$ directly targets CDK6, CCND1, CDK4, CCNE2, and MET (He et al. 2007, Sun et al. 2008). Therefore, miR-34a deficiency increases CDK activity with sequential $\mathrm{Rb}$ hyperphosphorylation in $\mathrm{G}_{1}, \mathrm{G}_{1}-\mathrm{S}$ transition, and initiation of DNA synthesis. Cyclin $\mathrm{G}_{1}$, an atypical cyclin upregulated by Arf-dependent p53 induction, is also a mediator of $\mathrm{Rb}$-dependent $\mathrm{G}_{1}$ growth arrest (Zhao et al. 2003).

Also, genotoxic stress promotes the p53-dependent upregulation of the homologous miRs $m i R-192$ and $m i R-215$. Like $m i R-34 a$, activation of $m i R-192 / 215$ induces cell cycle arrest, suggesting that multiple miR families operate in the p53 network (Braun et al. 2008, Georges et al. 2008).

This protective mechanism against uncontrolled cellular proliferation is lost in hepatocellular carcinomas by upregulation of $m i R-122 a$ (Gramantieri et al. 2007). miR-122 is a liver-specific miR (Chang et al. 2004) that is exploited by hepatitis $C$ virus infection (Jopling et al. 2005) and can specifically suppress the negative CCNG1 (Gramantieri et al. 2007), thereby favoring an unscheduled cell cycle progression.

Once cells have the ability to sustain their own survival and are insensitive to external inhibitory 
signals, tumorigenesis as an uncontrolled cell proliferation process is still kept in check by the apoptotic and senescent programs. Normal cells use these defense mechanisms in response to insults such as environmental stress (e.g. DNA-damaging agents, reactive oxygen species (ROS), and hypoxia) and oncogenic stress, activating them mostly in a p53-dependent manner. When these hedges are halted, cells can grow beyond their normal thresholds. The most common breach in these tumor suppressor barriers is represented by $\mathrm{p} 53$ abnormalities.

\section{Abnormal apoptosis}

Tissue homeostasis in normal cells is maintained by a perfect equilibrium of cell division and cell loss. Acquired resistance to PDCD (apoptosis) is a hallmark of all types of cancers. Apoptosis is a complex multistep process, which requires the involvement of numerous molecules. The apoptotic machinery consists of two families of components: sensors and effectors. The first class is composed of cell surface receptors that bind to survival or death factors: IGF1R, tumor necrosis factor- $\alpha$ (TNF- $\alpha$ ), TNF-related apoptosis-inducing ligand (TRAIL), and TNF-receptor superfamily member 6 (FAS) ligands. These signals usually regulate the second class of components, which function as effectors of cell death (members of the Bcl-2 family). Both families of apoptotic signals convey on the caspase cascade (i.e. caspases 8 and 9), which activates several additional effector caspases that execute the cell destruction program. Tumor cells are able to escape from the correct and complete execution of the apoptotic program despite being continuously exposed to proapoptotic stimuli (Letai 2008).

A regulatory path between miRs and apoptosis has been demonstrated at different levels in several cancer cell systems. Specifically, both the proapoptotic tumor suppressor p53-TP53 (Chang et al. 2007, Raver-Shapira et al. 2007, Welch et al. 2007) and antiapoptotic IL6/STAT3 (Löffler et al. 2007) pathways may regulate $\mathrm{miR}$ expression at the transcriptional level. Additionally, miRs may be able to induce (Cimmino et al. 2005) or repress (He et al. 2005a) apoptosis directly and autonomously by targeting antiapoptotic or proapoptotic proteins respectively.

Genomic regions frequently altered in cancers (e.g. fragile sites, minimal regions of loss of heterozygosity, minimal regions of amplification, and common breakpoint regions) have been characterized for their nonrandom association with $\mathrm{miR}$ genomic locations (Calin et al. 2004). For example, the cancer-associated genomic region $1 \mathrm{p} 36$, frequently lost or rearranged in many tumor types, contains candidate tumor suppressors (i.e. $\mathrm{CDH5}$ ) as well as important miRs, such as miR-34a (Cole et al. 2008, Hermeking 2009). The tumor-suppressive functions of $m i R-34 a$ have been extensively studied in many tumors, especially in human neuroblastomas (Welch et al. 2007, Cole et al. 2008, Wei et al. 2008) where its loss synergizes with MYCN amplification, which is in line with the fact that $m i R-34 a$ is a MYCN-negative regulator (Wei et al. 2008). $m i R-34 a$ is also able to induce cell cycle arrest and subsequent caspase-dependent apoptosis through Bcl-2 (Cole et al. 2008, Wei et al. 2008) and E2F3 repression (Welch et al. 2007). In addition, analysis of the transcriptome induced by $m i R-34$ overexpression exhibits high similarity to that observed with p53 induction, being highly enriched for genes regulating cell cycle progression, apoptosis, DNA repair, and angiogenesis (Bommer et al. 2007, Chang et al. 2007, He et al. 2007). Accordingly, miR-34 family members, as direct transcriptional targets of p53 (He et al. 2007), are essential for the correct execution of $\mathrm{p} 53$-dependent cellular responses. Although $m i R-34 a$ proapoptotic effects seem to be cell type-dependent, $m i R-34 a$ was proven to increase in a stress-induced renal carcinogenesis rat model, and its inhibition was shown to affect tumor cell proliferation (Dutta et al. 2007). miRs can also act upstream of p53. For example, $m i R-127$, another epigenetically silenced miR in tumors, seems to repress the protooncogene BCL6, a p53-negative regulator (Saito et al. 2006, Lujambio \& Esteller 2007).

A recently reported study showed that $m i R-330$ expression was significantly lower, and that this induced apoptosis in human prostate cancer cell lines (Lee et al. 2009). Bioinformatics analyses revealed a conserved target site for $m i R-330$ in the $3^{\prime}$ UTR of E2F1. The same study reported that the expression level of $m i R-330$ and E2F1 was inversely correlated in cell lines and prostate cancer specimens, and that E2F1 was negatively regulated by $m i R-330$. Additionally, $m i R-330$ was able to induce apoptosis in prostate cancer cells through E2F1-mediated suppression of Akt phosphorylation (Lee et al. 2009).

$m i R-21$ overexpression is a trait common to several malignancies (Volinia et al. 2006, Hiyoshi et al. 2009, Yamamichi et al. 2009). miR-21 acts predominantly as an antiapoptotic protein by blocking the expression of critical apoptosis-related genes (Chan et al. 2005). Among miR-21 apoptotic targets are the tumor suppressor PDCD4 in breast cancer cells (Frankel et al. 2008, Lu et al. 2008) and the tumor suppressor PTEN in hepatocellular cancer (HCC) cells (Meng et al. 2006). miR-21 favors the transmission of 
antiapoptotic survival signals through the PI3K-Akt pathway. Additionally, miR-21 indirectly supports Bcl-2 antiapoptotic activities (Si et al. 2007). Therefore, repression of $m i R-21$ should sensitize cells to therapeutic strategies inducing apoptosis, as demonstrated in a glioma model, by combining neural precursor cells expressing secreted TRAIL with antimiR-21 oligonucleotides (Corsten et al. 2007).

The miR relevance to the TRAIL apoptotic pathway has been dissected with an RNA interference screening strategy, and many miRs (let-7c, miR-10a, miR-144, $m i R-150, m i R-155$, and $m i R-193$ ) were found to affect the activation of the caspase cascade. All of the identified miRs displayed as putative target genes encoding death receptors, caspases, and other apoptosis-related genes (Ovcharenko et al. 2007). For $m i R-155$, among others, the stress-induced proapoptotic protein TP53BP1 has been shown to be a target in pancreatic tumors and to be responsible for part of miR-155 protumorigenic effects (Gironella et al. 2007).

\section{Limitless replicative potential of tumors}

Normal cells have the capacity for a finite number of cell divisions, also called limited replicative potential; normally, the cells stop proliferating and enter into a state of cellular senescence, which is a physiological withdrawal from the cell cycle in response to numerous stimuli. To ensure expansive tumor growth, a tumor cell needs to acquire additional programs independently from the cell-cell signaling described above. Disruption of the limited replicative potential leads tumor cells to expand to a macroscopic size. Senescent cells present different morphology, express senescence-associated $\beta$-galactosidase, and are insensitive to proliferative stimuli (Dimri et al. 1995). In normal cells, the most important players of the senescent program are $\mathrm{p} 53, \mathrm{Rb}$, and $\mathrm{p} 16^{\mathrm{INK} 4 \mathrm{a}}$ (Campisi 2005). Cells reach senescence when they complete the allowed number of doubling, entering a state of permanent proliferative arrest. This is known as 'replicative senescence' and is due to the progressive erosion of telomeres, which is sensed by the cell as DNA damage.

Tumor cells may circumvent replicative senescence and acquire a limitless replicative potential either by abnormal telomerase enzyme activation, alternative lengthening of telomeres, or by homologous recombination events at telomeres (Bailey et al. 2004). The senescent program is kept in check in tumor cells by expression of the Polycomb repressor B lymphoma Mo-MLV insertion region 1 homolog
(BMI; Grinstein \& Wernet 2007). Telomerase maintenance is present in virtually all types of malignant cells, with different neoplasms presenting heterogeneous cell populations differing in their replicative potential. While most cancer cells have limited replicative potential, small subpopulations (i.e. cancer stem cells) have an infinite replicative capacity to reconstitute the tumor. Alterations of telomere dynamics and telomerase are also described in the progression of many tumors (Stewart \& Weinberg 2000).

Replicative senescence can be accelerated by DNAdamaging agents, ROS, and uncontrolled oncogene activation. Hyperactive oncogenes are especially responsible for a high degree of stalling and collapsing of replication forks, causing DNA double-strand breaks and facilitating a DNA damage response (Bartek \& Lukas 2006, Bartek et al. 2007). The molecular mechanisms underlying the escape from senescence include loss of the TP53 and telomerase maintenance.

miRs have been shown to be relevant in diverting oncogene-induced premature senescence. $m i R-373$ and $m i R-372$ were identified as capable of allowing transformation of primary cells harboring oncogenic RAS and wild-type p53 by neutralizing p53-mediated CDK inhibition through suppression of LATS2 (Voorhoeve et al. 2006).

Not surprisingly, telomerase deregulation can be achieved by tumors through a reduction in normal expression levels of $m i R-138$, which can repress TERT mRNA translation, as shown in undifferentiated and differentiated thyroid cancer cell lines (Mitomo et al. 2008).

Epigenetic mechanisms are also involved in telomere homeostasis, and recently, they have been shown to be controlled by $m i R-290$ cluster The $m i R-290$ family is able to target the $R B L 2$ transcription factor, which in turn controls expression of DNMT3A and DNMT3B methylating enzymes that maintain telomere length (Benetti et al. 2008). To date, the relevance of this mechanism has not been directly assessed in cancer models.

Concerning senescence, $\mathrm{p} 53$-activated miRs are also important. The $m i R-34$ family of all transcriptional targets participates in the senescent program (Kumamoto et al. 2008) through modulation, at least for $m i R-34 a$, of the E2F signaling pathway (Tazawa et al. 2007). Of note, recently RGM249 (RNA gene for miRs) was discovered, which could be among the first $\mathrm{miR}$ precursor genes that are involved in the differentiation and function upstream of hTERT in tumor cells (Miura et al. 2009). 


\section{Induction and sustained angiogenesis}

In normal tissues, growth of new vessels (angiogenesis) is transitory and finely regulated, whereas tumor cells - in order to proliferate and induce and sustain neovascularization - need to turn on the 'angiogenic switch', thereby producing high amounts of proangiogenic factors (Semenza 2000, Tanaka et al. 2003). The rapid expansion of tumor cells creates a hypoxic environment, leading to tumor necrosis and inducing cell adaptation responses, such as hypoxiainduced factor (HIF)-dependent survival pathways and angiogenesis. Quiescent endothelial cells are thus activated and recruited by angiogenic factors, and stimulated to proliferate and form new blood vessels. Tumors count on their angiogenic potential to outgrow locally and spread to distant sites, and increased angiogenesis has been correlated with a poor prognostic outcome for patients with many types of tumors (Semenza 2003).

Recent reports have established a link between hypoxia, a key feature of the tumor microenvironment, and a group of miRs, in part explained by direct HIF1 transcriptional activation of specific miRs (Kulshreshtha et al. 2007). Microarray-based expression profiles found that a specific spectrum of miRs, including $m i R-23, m i R-24, m i R-26, m i R-27, m i R-103$, $m i R-107, m i R-181, m i R-210$, and $m i R-213$, is induced in response to low oxygen. These miRs may act by decreasing proapoptotic signal-sustaining cell survival ( $m i R-26$ family, miR-107, and miR-210) (Kulshreshtha et al. 2007) or by participating in the angiogenic process. miRs may participate in the angiogenic process like miR-210 through direct repression of the endothelial ligand Ephrin A, which partially regulates endothelial cell chemotaxis and tubulogenesis (Fasanaro et al. 2008), or like $m i R-27 a$, which represses $Z B T B 10$ (zinc finger gene), thereby inducing specific protein-dependent transcription of both survival and angiogenic genes, such as survivin, VEGF, and VEGFRs (Mertens-Talcott et al. 2007).

A link between miRs and angiogenesis was initially investigated in Dicer knockout mice, which display angiogenic defects during embryogenesis (Yang et al. 2005). Further studies based on genetic silencing of DROSHA and DICERI in human endothelial cells confirmed the involvement of miRs in angiogenesis (Kuehbacher et al. 2007, Súrez et al. 2007). In particular, lef- $7 f$ and mir-27b expression was strongly reduced, and the let-7 family was proven to downregulate the antiangiogenic thrombospondin-1 (TSP1).

The most important angiogenic factor is the VEGF, which is highly expressed in several tumors. VEGF is regulated at multiple levels (both transcriptional and translational) downstream of a wide range of stimuli, such as hypoxia, HIF1, growth factors, cytokines, and hormones (Loureiro \& D'Amore 2005). Recently, it has been shown that VEGF is also restrained at the posttranscriptional level by miRs. For example, miRs downregulated in hypoxic conditions, such as miR-16, $m i R-15 a, m i R-20 a$, and $m i R-20 b$, modulate VEGF expression levels, thereby supporting the angiogenic process (Hua et al. 2006). This creates a positive regulation loop in which hypoxia-repressed miRs reinforce the expression levels of a potent proangiogenic hypoxia-induced growth factor such as VEGF (Hua et al. 2006).

MYC is also a VEGF transcription activator promoting neovascularization in tumor cells. Colonocytes expressing c-Myc showed upregulation of miR-17-92, repressing TSP1 and related proteins such as connective tissue growth factor (CTGF), whereas miR-17-92 knockdown cells restored TSP1 and CTGF expression and formed larger and better perfused tumors. These findings established a role for miRs in noncellautonomous MYC-induced tumor phenotypes (Dews et al. 2006). Two additional miRs, $m i R-18$ and $m i R-19$, are responsible for CTGF and TSP1 repression respectively (Dews et al. 2006), both of which are important for angiogenesis and ECM remodeling.

Another important mechanism in angiogenesis is the upregulation of growth factor receptors on endothelial cells. $m i R-296$ has been shown to play a major role in this process. Growth factor-induced miR-296 contributes significantly to angiogenesis by directly targeting the hepatocyte growth factor-regulated tyrosine kinase substrate (HGS) mRNA, leading to decreased levels of HGS and thereby reducing HGS-mediated degradation of the growth factor receptors VEGFR2 and PDGFR- $\beta$ (Würdinger et al. 2008). However, miRs may have different expressions and functions in different tissues (tissue-specific functions). For example, loss of $m i R-221$ and $m i R-222$ in endothelial cells sustains the proliferative and angiogenic properties of KIT, whereas upregulation of $m i R-221$ and $m i R-222$, which is commonly observed in tumor cells, regulates the CKI p27 (le Sage et al. 2007), increasing cell proliferation and enhancing their metastatic potential (Baldassarre et al. 2005, Chu et al. 2008). Similarly, $m i R-126$ has an increased expression in endothelial cells, where it sustains proangiogenic factor signals through SPRED1 and PI3K regulatory subunit 2 (PI3KR2) repression (Fish et al. 2008), and its downregulation in tumor cells contributes to abnormal proliferation. 
The angiogenic switch is controlled at the transcriptional level by the developmental homeobox genes, which can be grouped as pro- or antiangiogenic (Gorski \& Walsh 2003). The antiangiogenic Gax homeobox genes are highly expressed in quiescent endothelial cells and are rapidly downregulated after mitogenic and proangiogenic signals. $m i R-130 a$, a miR involved in megakaryocytic differentiation and expressed by endothelial cells, was observed to be triggered by angiogenic stimuli in a reciprocal way compared to $G A X$. Accordingly, it was shown that $m i R-130 a$ directly represses (at the posttranscriptional level) the expression of $G A X$ and (to a lesser extent) the expression of a similar antiangiogenic factor, such as HOXA5, thereby allowing the angiogenic process (Chen \& Gorski 2008).

\section{Tumor invasion and metastasis}

The spread of tumor cells to locoregional and distant sites requires that the cells detach from the primary tumor, enter the blood or lymphatic system (Chambers et al. 2002, Sahai 2007), and infiltrate and disseminate in the ECM as single cells or expand in solid cell strands, sheets, files, or clusters (Friedl 2004). This metastatic capability required by the cells is associated with genetic-biochemical alterations of cell-cell and cell-matrix interactions. Some tumors (e.g. sarcoma) disseminate via single cells, whereas epithelial tumors commonly use a collective migration mechanism (Friedl 2004). In particular, epithelial cells preferentially use a protease-dependent mesenchymal strategy that allows degrading ECM barriers and cells to move (Wolf et al. 2003, Friedl 2004).

Tissue invasion and metastases often require different cell capabilities (e.g. detachment from the primary tumor and adhesion to distant metastatic sites), suggesting a fast cellular adaptation and clonal selection that only a small subset of cancer cells will overcome (Wong et al. 2001). Overall, the efficiency of the metastatic process is correlated with increased cell survival (Kim et al. 2004); in fact, oncogenes that promote cell proliferation and survival in the primary tumor, such as $B C L 2$ or active $R A S$, are also involved in promoting malignant cell survival at metastatic sites (Wong et al. 2001). Additionally, cells at metastatic sites must display high replicative potential, as proposed by the model in which macroscopic metastases are formed only when the self-renewing 'cancer stem cell' arrives at a secondary site (Bjerkvig et al. 2005).

An increasing number of studies have revealed miR signatures of metastasis and have shown that the targets of most of these metastasis-associated miRs are proteins involved in the regulation of cell motility, cell-cell adhesion, and cell-matrix interactions.

$m i R-29 c$, which is significantly reduced in highly invasive and metastatic nasopharyngeal carcinoma, has as preferential targets the genes encoding for ECM proteins, such as collagen or laminin- $\gamma$ (Sengupta et al. 2008), further supporting the model in which the composition of the local microenvironment is an important variable in the ability of cancer cells to properly move and/or survive. Similarly, downmodulation of the adhesion molecule CD44, induced by $m i R-373$ and $m i R-520 c$ in a breast cancer model, could explain their effect as metastasis-promoting miRs. In fact, CD44 is frequently upregulated in a wide variety of malignancies (Ponta et al. 2003, Marhaba et al. 2008), and CD44 modulates cell adhesiveness, motility, matrix degradation, proliferation, and survival - all traits that allow a tumor cell to progress through the metastatic cascade (Marhaba \& Zoller 2004, Asangani et al. 2008, Zhu et al. 2008). Alterations in cytoskeletal protein expression levels by miRs can affect cell morphology and motility, as has been proven for $m i R-21$, which can reduce the levels of tropomyosin 1 and affect cell invasion (Marhaba \& Zoller 2004, Asangani et al. 2008, Zhu et al. 2008). In addition, $m i R-21$, by acting on PTEN, potentiates tumor cell metastatic abilities by favoring the Akt survival pathway and the Akt-dependent modulation of focal adhesion kinase phosphorylation and matrix metalloprotease expression levels (Meng et al. 2007). miR-21 has an important role in the tumor progression of several neoplasms, including directly targeting MARCKS and promoting apoptosis resistance and invasion in prostate cancer cells ( $\mathrm{Li}$ et al. 2009b); regulating proliferation and invasion in esophageal squamous cell carcinoma (Hiyoshi et al. 2009); posttranscriptionally downregulating the tumor suppressor PDCD4, stimulating invasion, intravasation, and metastasis in colorectal cancer (Asangani et al. 2008); and regulating tumor progression in several additional tumors. Another study reported that miR-122, a marker of hepatocytespecific differentiation, is specifically repressed in a subset of primary tumors characterized by poor prognosis, and that loss of $m i R-122$ expression in tumor cells segregates with specific gene expression profiles linked to cancer progression and invasion. Loss of $m i R-122$ resulted in an increase in cell migration and invasion (Coulouarn et al. 2009). Downregulation of $m i R-221$ has been shown to be negatively correlated with the expression of the protooncogene $c$-kit in primary prostate carcinoma. In a large study cohort, $m i R-221$ was progressively 
downregulated in aggressive forms of prostate carcinoma. Downregulation of $m i R-221$ was associated with clinicopathological parameters, including the Gleason score and clinical recurrence during follow-up. Statistical models showed that $m i R-221$ downregulation was linked to tumor progression and recurrence in a high-risk prostate cancer cohort, making this miR an important prognostic factor in high-risk prostate carcinoma (Spahn et al. 2009).

More interesting is the role of the miR-200 family, which has been recently associated with the epithelialmesenchymal transition (EMT) process (Gregory et al. 2008, Korpal et al. 2008, Park et al. 2008). An EMTlike process occurs as part of embryonic development and during carcinogenesis when tumor cells undergo a change from a differentiated to a dedifferentiated form, leading to a more invasive cell phenotype. This is an adaptation response, a migratory escape strategy, occurring during the course of tumor progression (Friedl 2004) where adherens junctions and desmosomes become partially dissociated and epithelial cells switch from a collective invasion pattern to a detached and disseminated cell migration method (Friedl \& Wolf 2003). All members of the miR-200 family, usually together with $m i R-205$, are significantly downmodulated during the EMT process (Gregory et al. 2008). These miRs are able to regulate the expression of key transcription factors belonging to the E-boxbinding family (such as Snail, Slug, ZEB1, and ZEB2/ SIP-1) involved in the EMT and in tumor invasion and metastasis, which in turn regulate several EMT-related genes, such as epithelial (E)-cadherin, mucin, tight junction protein ZO3, connexin 26, and plakophilin 2 (Peinado et al. 2007). In particular, one of the ZEB1 targets is represented by a typical epithelial marker $(\mathrm{CDH1})$ that is lost during the first step of EMT. Recent observations strengthen the role of the miR-200-ZEBI axis in EMT, demonstrating that on the one hand $m i R-200$ regulates ZEB1 expression and on the other hand ZEB1 regulates miR-200 transcription (Burk et al. 2008), thus establishing a complex regulatory loop that may ensure the tight superintendence of the EMT process.

Given the fact that $m i R-373$ can act as a direct transcriptional activator of $C D H 1$, it is possible that its loss during the metastatic process might also contribute to the EMT process (Place et al. 2008).

The reverse of EMT, MET, also occurs in carcinogenesis and certainly is regulated by this miR family. However, whereas EMT during cancer progression is well characterized, MET is more difficult to observe in vivo.
An important study found an intriguing loss of expression of $m i R-200$ in advanced breast cancer, where these miRs seem to regulate several oncogenic functions (Gregory et al. 2008). A dissimilar pattern of expression of this miR family has been found in different studies on ovarian cancer, most likely reflecting differences in the selection, amount, and composition of tumoral and nontumoral cells analyzed (see the review by Peter (2009)).

Crosstalk occurs between $m i R-200$ and let-7 at different levels during carcinogenesis. Let-7 is an important regulator of cell differentiation. Although let-7 is unlikely to be a direct EMT regulator (Park et al. 2007, Shell et al. 2007), many factors are regulated by both miR families; for example, HMGA2 is directly regulated by let-7, and HMGA2 is often required for TGF- $\beta$-induced EMT of mouse mammary epithelial cells regulating Snail, Slug, Id2, and Twist. More recently, it was also demonstrated that ZEB1 and ZEB2 could be regulated by HMGA2, and that the regulation of Snail promoter by HMGA2 involves binding of this factor to Smad3 and Smad4 (Thuault et al. 2008). In addition, RAS, which is another target of let-7 and a driving force for EMT, has been reported to induce HMGA2 expression (Tchernitsa et al. 2004). These two miR families could interact and be considered part of a system loop regulating dedifferentiation processes, such as EMT, and stem cells and stem cell-like properties.

$m i R-155$ is another important factor contributing to TGF-induced epithelial cell plasticity and therefore to cell migration and invasiveness. It has been found to be a downstream effector of TGF and Smad4 and to partially account for TGF-induced RhoA suppression and therefore responsible for the dissolution of cell tight junctions (Kong et al. 2008). Consistently, $m i R-155$ has been reported to be upregulated in invasive breast cancer, supporting its involvement in breast cancer metastasis (Iorio et al. 2005, Volinia et al. 2006).

Epigenetic alterations with upregulated EP300targeting miRs miR-194, miR-200b, miR-200c, and $m i R-429$ were correlated with reduced EP300 mRNA and protein in highly metastatic pancreatic ductal adenocarcinoma (PDAC) cells (Mees et al. 2009a). Another study by Mees et al. (2009b) showed that upregulated CD40-targeting miR-224 and miR-486 are related to downregulated CD40 protein expression at cell surfaces in highly invasive and metastatic PDAC. These results demonstrated that miRs might be able to modulate the expression of metastasis-specific suppressor genes and metastatic behavior. 
Cancer cells have the potential to adopt different types of motility to successfully spread to distant organs. The faster one (amoeboid motility) is accompanied by increased activation of Rho pathways. Interestingly, two different works on breast cancer metastasis formation independently identified miRs that were able to trigger Rho pathways (Ma et al. 2007, Bhaumik et al. 2008). miR-10b overexpression indirectly increases, by repression of its negative transcriptional regulator, $\mathrm{RhoC}$ protein levels, leading to increased cell motility and metastasis formation in breast tumors (Ma et al. 2007). $m i R-146 a$ expression is lost in metastatic breast cancer, and this loss has been documented as directly inhibiting the expression of the Rho target ROCK1 affecting cell movements (Bhaumik et al. 2008). In a similar fashion, $m i R-31$ mediates the inhibition of several steps during breast cancer metastasis, including local invasion, extravasation or initial survival at a distant site, and metastatic colonization. Such pleiotropy is achieved via coordinate repression of a cohort of metastasis-promoting genes, including RhoA (Valastyan et al. 2009). Indeed, RhoA re-expression partially reverses $m i R$-31-imposed metastasis suppression. These findings indicate that miR-31 uses multiple mechanisms to oppose metastasis. Thus, it seems likely that the proposed mesenchymal to amoeboid transition, first identified only in vitro (Wang et al. 2006), can actually play an important role in metastasis formation, and that metastatic deregulated miRs may impinge on this pathway to promote in vivo cell dissemination in different types of tumors. A recent study reported how metastatic cells not only downregulate $m i R-335$, inhibiting cell motility, but also downregulate $m i R-126$, which inhibits cell proliferation (Tavazoie et al. 2008). As mentioned above, both proliferation and migration advantages are important steps of the metastatic process; therefore, ablation of both $m i R-126$ and miR-335 is necessary for tumor metastasis in vivo (Tavazoie et al. 2008). miR-335 acts, as does $m i R-29 c$, by modulating the ECM composition targeting the tenascin and also by halting gene differentiation programs, acting on the transcription factor SOX4.

$m i R-34 b, m i R-34 c$, and $m i R-199 a$ are able to regulate the MET receptor and the invasive growth program, both in cells expressing normal levels of MET and in cancer cells overexpressing a constitutively active MET. The same miRs play a role in regulating the MET-induced migratory ability of melanoma-derived primary cells (Migliore et al. 2008).

\section{Expression profile of $\mathrm{miR}$ in endocrine tumors}

The miR profiles are surprisingly informative, reflecting the developmental lineage and differentiation and successfully classifying the tumors (Lu et al. 2005). Usually, we observe a general deregulation (up- or downregulation) of miRs in tumors compared with normal tissue. The deregulated miR expression profile in human cancer may prove a powerful tool for cancer detection, diagnosis, classification, and prognosis. Endocrine tumors represent a wide and heterogeneous family of tumors originating in endocrine glands. In Table 1, we have summarized all important deregulated miRs found to be associated with the pathogenesis of endocrine tumors. For each of these tumors, we provide a brief description of known important deregulated miRs discovered by miR expression profiling.

\section{Breast cancer}

Breast cancer is one of the most interesting cancers to investigate because of the different components in the mammary gland during embryogenesis, the wide variety of different tumor histotypes, and the high number of heterogeneous cell subpopulations. miR profiles in breast tumor samples have identified a variety of deregulated miRs (Iorio et al. 2005, Volinia et al. 2006, Ma et al. 2007, Huang et al. 2008, Tavazoie et al. 2008). Iorio et al. (2008) and Shi \& Guo (2009) nicely summarized the most common deregulated miRs in breast cancers, including the upregulation of miR-21 (targeting Bcl-2, TPM1, and PDCD4), miR-155, $m i R-206$ (ER- $\alpha$ ), $m i R-373$, and $m i R-520$, and the downregulation of $m i R-125 a / b$ (ERRB2-ERRB3), miR-145, miR-10b (HOXD10), miR-9-1, let-7, $m i R-27 a$, and $m i R-17-5 p$; the latter two miRs play an oncogenic role in breast cancer cell lines. Some of these miRs, such as $m i R-10 b, m i R-373$, and $m i R-520$, have also been shown to play a role in tumor invasion and breast cancer metastasis; others, such as $m i R-335$, $m i R-126$, and $m i R-206$, act as metastasis suppressors (Tavazoie et al. 2008). Four additional miRs ( $m i R-7$, $m i R-128 a$, miR-210, and miR-516-3p) have been associated with breast cancer progression and distinct biological pathways (Foekens et al. 2008). Additional miRs from the miR-200 family, in conjunction with $m i R-205$, have been shown to regulate the epithelial and mesenchymal status of breast cancer cells and progression of tumors (Hurteau et al. 2007, Sempere et al. 2007, Burk et al. 2008, Gregory et al. 2008). The role played by $m i R-200$ in stemness regulation of breast cancer cells is interesting. A recent study showed that $m i R-200 \mathrm{c}$ is able to regulate the expression 
of BMI1, a known regulator of stem cell self-renewal. $m i R-200 c$ inhibited the clonal expansion of breast cancer cells and suppressed the growth of embryonal carcinoma cells in vitro. Most importantly, miR-200c strongly suppressed the ability of normal mammary stem cells to form mammary ducts and tumor formation driven by human breast cancer stem cells in vivo (Shimono et al. 2009).

\section{Prostate tumors}

Prostate cancer typically is composed of very small, multiple primary tumors within the prostate gland. At an early stage, the disease is often curable, although the cancer produces few or no symptoms and can be difficult to be detected. In most cases, prostate cancer is a relatively slow-growing cancer; however, a small percentage of patients experience more rapidly growing, aggressive forms of prostate cancer. miR expression profiles have identified important miRs in prostate cancer. Among these, $m i R-15 a$ and $m i R-16$ act as tumor suppressor genes through the control of cell survival, proliferation, and invasion (Bonci et al. 2008). $m i R-146 a$ is downregulated in hormonerefractory prostate cancers (Lin et al. 2008), and $m i R-21$ is overexpressed and functions as an oncogene by a mechanism that involves translational repression of the tumor suppressor PDCD4 (Lu et al. 2008). Among the downregulated miRs are the $m i R-106 b-25$ cluster targeting E2F1 and p21/WAF1 (Ambs et al. 2008); miR-221 (targeting c-kit) and miR-101 (targeting the histone methyltransferase EZH2), which are progressively reduced in aggressive prostate cancer and metastasis (Varambally et al. 2008, Spahn et al. 2009); miR-449, which regulates cell growth and viability in part by repressing the expression of histone deacetylase 1 in prostate cancer cells (Noonan et al. 2009); miR-331-3p, which can regulate signaling pathways critical to the development and progression of prostate cancer cells (Epis et al. 2009); miR-205 and miR-200 (PC3 cells), which exert a tumor-suppressive effect in the human prostate by counteracting EMT and reducing cell migration and invasion (Gandellini et al. 2009, Kong et al. 2009). Other deregulated miRs include $m i R-222, m R-373, m i R-125 a / b, m i R-181$, and let-7 families (Volinia et al. 2006, Galardi et al. 2007, Porkka et al. 2007).

\section{Ovarian cancers}

Ovarian cancer remains a leading cause of morbidity and mortality, with little change in survival rates over the past 30 years. Deregulation of miRs has been found to be associated with ovarian cancer. Two different studies showed that the most deregulated miRs in ovarian cancers were $m i R-15-16, m i R-29 a / b, m i R-30 b / d$, miR-181b (Zhang et al. 2006), miR-105, miR-143, $m i R-203$, and $m i R-373$ (Iorio et al. 2007), with $m i R-9$, $m i R-34, m i R-140$, and let-7 commonly altered in both studies. Discordance in the expression of miR-200 members has been reported in different studies. When ovaries from patients with ovarian cancer were compared with ovaries or ovarian surface epithelial cells from healthy patients, $m i R-200$ was found to be upregulated in tumors (Iorio et al. 2007, Nam et al. 2008, Yang et al. 2008); however, a recent study reported no change in $m i R-200$ expression (Dahiya et al. 2008), and another reported the downregulation of this family of miRs (Zhang et al. 2008) (for further details, see section titled 'Tumor Invasion and Metastasis').

\section{Liver cancers}

The majority of primary liver cancers (over 95\%) arise from liver cells and are called HCCs or carcinomas. Downregulation of $m i R-34 a$ expression has been reported in human HCCs and was associated with metastasis and invasion of tumors. In HepG2 cells, ectopic expression of $m i R-34 a$ potently inhibited tumor cell migration and invasion in a c-Met-dependent manner, in turn decreasing c-Met-induced phosphorylation of ERKs 1/2 (Li et al. 2009a). In other HCC cells (SKHep1C3), overexpression of $m i R-23 b$ led to urokinase-type plasminogen activator and c-Met downregulation and to decreased migration and proliferation abilities (Salvi et al. 2009). miR-26a has been shown to be an important miR in MYC-induced hepatocarcinoma, inducing $\mathrm{G}_{1}$ arrest in human liver cancer cells (Kota et al. 2009). miR-101 is downregulated in hepatocellular carcinoma, promotes apoptosis, and suppresses tumorigenicity ( $\mathrm{Su}$ et al. 2009). Additional miRs have been shown to play different but important roles in hepatocarcinoma (see the review by Gramantieri et al. (2008)), such as downregulation of $m i R-1$ and $m i R-199 a$ regulating HGF/MET, downregulation of let-7 and upregulation of $m i R-21$ regulating the RAS and PI3K pathways respectively, and upregulation of $m i R-221$ and $m i R-222$ implicated in the regulation of cell cycle progression through repression of p27 and p57. The role of the tumor suppressor miR-122 in this type of cancer is noteworthy. Loss of $m i R-122$ expression in tumor cells has been linked to cancer progression, where transcription factors HNF1A, HNF3A, and HNF3B are able to regulate the expression of miR-122 (Coulouarn et al. 2009). miR-122 regulates 
the expression of cyclin $G_{1}$, and the interaction miR-122-cyclin $\mathrm{G}_{1}$ modulated the activity of the tumor suppressor p53 (Fornari et al. 2009).

\section{Pancreatic cancers}

Pancreatic cancer is a lethal disease characterized by multiple genetic alterations. The strategies currently available for diagnosis and treatment of pancreatic cancer are not satisfactory, and specific markers to identify this tumor are very scarce. Four studies have identified a pancreatic miR signature, and miR-216 emerged as the only pancreas-specific miR (see review by Seux et al. (2009)). A recent study reported a differential expression that was significantly dissimilar between tumors and chronic pancreatitis, a normal pancreas, pancreatic cellular lines, and adjacent normal samples. A list of $20 \mathrm{miRs}$ as signatures of PDAC was reported, with most (miR-155, miR-221, miR-100, miR-125b-1, miR-21, miR-181a/c, miR-107, miR-424, miR-301, miR-212, miR-92-1, miR-16-1, let-7d/f1, let-15b, let-24-1/2, and let-376a) being found to be upregulated and only a few downregulated (miR-139, $m i R-345$, and $m i R-142 p$ ) (Jiang et al. 2005). In a second study, Szafranska et al. (2007) used an array containing a limited number of miRs and identified differences between pancreatic cancer, normal pancreas, chronic pancreatitis, and PDAC-derived cell lines. They selected a set of 26 miRs deregulated in PDAC as signature of disease. In a third study, Bloomston et al. (2007) compared miR expression in 65 microdissected PDAC cells in the adjacent noncancerous pancreatic tissue, and in a set of chronic pancreatitis specimens. Cluster analysis demonstrated that $30 \mathrm{miRs}$ were upregulated and three were downregulated in pancreatic cancers compared with normal pancreatic tissue. Similar to the other two studies, they found that chronic pancreatitis and normal pancreatic specimens showed similar expression patterns, whereas patterns of normal tissue and pancreatic cancer were clearly distinct. All three studies showed a preponderant number of upregulated miRs. $m i R-155$ and $m i R-221$ were commonly found to be deregulated in all three studies. Furthermore, some miRs and genes have been shown to have mechanisms of cross-regulation. For example, loss of TP53INP1 was due to the activity of the oncogenic $m i R-155$, which is overexpressed in pancreatic cancer cells. Moreover, p53 inactivation partially contributed to the reduction in $m i R-34 a$ levels, which raises the possibility that $m i R-34 a$ loss of function contributes to pancreatic cancer pathogenesis (see review by Seux et al. (2009)).

\section{Gastric cancers}

Gastric cancer is the fourth most common cancer worldwide. Metastasis occurs in $80-90 \%$ of individuals, and this disease has a high death rate, making it the second most common cause of cancer death worldwide. Only a few miRs have been confirmed to be relevant in the tumorigenesis of gastric cancer. miR-451 was detected by in situ hybridization in epithelial gastric cells; however, decreased expression in gastric cancer samples was associated with a worse prognosis (Bandres et al. 2009). The expression levels of $m i R-31, m i R-141, m i R-143$, and $m i R-145$ have been shown to be significantly downregulated in gastric cancer tissue and to be involved in the pathogenesis of this type of tumor (Du et al. 2009, Takagi et al. 2009, Zhang et al. 2009), whereas $m i R-21$ has been reported to be upregulated and involved in tumor progression (Volinia et al. 2006, Zhang et al. 2008). A study showed that HMGA2, which correlates with tumor invasiveness in gastric cancer, is negatively regulated by the let-7 $\mathrm{miR}$ family (Motoyama et al. 2008). Further investigations are needed to identify specific miRs involved in the pathobiology of these aggressive tumors.

\section{Thyroid tumors}

Thyroid cancer may occur either in the follicular cells or in parafollicular C-cells, basically giving origin to four main types of thyroid cancers: papillary, follicular, anaplastic, and medullary. He et al. (2005b) were the first to report the upregulation of $m i R-221, m i R-222$, $m i R-146, m i R-21, m i R-220, m i R-181$, and $m i R-155$, and the downregulation of $m i R-138, m i R-219, m i R-26 a$, and $m i R-345$ in PTCs. Additional studies confirmed $m i R-221, m i R-222$, and $m i R-181 b$ as potential signatures for PTC (Pallante et al. 2006), and found that $m i R-221$ and $m i R$-222 were able to reduce p27kipl protein expression (Visone et al. 2007a). Another study confirmed the abnormal regulation of $m i R-221$ and $m i R-222$ in thyroid tumors (Nikiforova et al. 2008). miR-30d, miR-125b, miR-26a, miR-138, and miR-30a-5p were found to be downregulated and $m i R-222$ was found to be upregulated in anaplastic thyroid carcinoma (ATC; Visone et al. 2007b). An additional ATC study showed an upregulation of $m i R-221, m i R-222$, $m i R-21$, and $m i R-146 b$ in ATC and PTC with downregulation of $m i R-26 a, m i R-219, m i R-345$, and $m i R-138$ only in ATC. $m i R-138$ was shown to regulate hTERT (Mitomo et al. 2008). Overexpression of $m i R-17-92$ cluster, $m i R-106 a / b$, and $m i R-17-3 p / 5 p$ was also reported in ATC cell lines (Takakura et al. 2008). The finding of a common single nucleotide 
polymorphism (SNP: rs2910164) in pre-miR-146a, affecting the miR expression itself, is noteworthy. This SNP has been shown to profoundly affect downstream transcripts because of the production of different mature miRs, thus contributing to the genetic predisposition of PTC (Jazdzewski et al. 2008, 2009). Additional downregulated miRs, such as miR-197, $m i R-346$, miR-192, and $m i R-328$, have been described in follicular thyroid carcinoma (Weber et al. 2006). Despite BRAF V600E mutation, which can affect the transcriptome levels in PTC, an interesting study reported that this particular genetic alteration was not able to significantly affect miR expression (Sheu et al. 2009).

\section{Adrenal tumors}

Each adrenal gland has two main parts that function separately - the adrenal cortex and medulla. A recent study reported the involvement of miRs in the tumors originating in this gland. Tumors may originate in both components, giving rise to three main tumor groups: adrenocortical carcinoma, pheochromocytoma, and neuroblastoma. The latter cancer accounts for $15 \%$ of all childhood cancer deaths, and dysregulation of some miRs, including the $m i R-17-5 p-92$ cluster and $m i R-34 a$, has been implicated in the pathobiology of this type of devastating cancer. $m i R-17-5 p-92$ family members act in an oncogenic manner, whereas $m i R-34 a$ has tumor suppressor functions (O'Donnell et al. 2005, Welch et al. 2007, Chayka et al. 2009). In neuroblastomas, the oncogene MYCN regulates the miR-17-5p-92 cluster, which in turn inhibits p21 and BIM translation by interaction with their mRNA $3^{\prime}$ UTRs (Fontana et al. 2008), therefore identifying a new mechanism of tumor progression in these types of tumors. Additionally, three neuronal miRs ( $m i R-9, m i R-125 a$, and $m i R-125 b$ ) have been shown to control human neuroblastoma cell proliferation (Laneve et al. 2007) by repressing a common target, the truncated isoform of the neurotrophin receptor tropomyosin-related kinase C, a critical isoform for regulating neuroblastoma cell growth. $m i R-221$ is another important overexpressed miR that has been shown to induce MYCN in neuroblastoma (Schulte et al. 2008).

$m i R-21$ is an endogenously expressed miR in human adrenal cells; however, miR-21 expression is upregulated by angiotensin II, and its overexpression causes an increase in aldosterone secretion and cell proliferation (Romero et al. 2008). Deregulation of specific miRs has been reported in adrenocortical tumors, with higher expression of $m i R-184$ and $m i R-503$ and lower expression of $m i R-511$ and $m i R-214$ in ACCs than in adenomas and normal adrenal glands, although expression of $m i R-210$ was significantly lower in cortisol-secreting adenomas than in ACCs (Tömböl et al. 2009). Upregulation of $m i R-449$ has been reported to be associated with a bilateral form of adrenal hyperplasia often associated with Carney complex (Iliopoulos et al. 2009).

\section{Pituitary tumors}

The pituitary gland is linked in function to the hypothalamus. It is composed of two lobes - the anterior pituitary (adenohypophysis) and the posterior pituitary (neurohypophysis). It secretes hormones regulating homeostasis, including tropic hormones that stimulate other endocrine glands. Symptoms of pituitary adenomas can vary considerably, depending on whether the tumor is secreting one or more of a variety of hormones. Dysregulation of miRs has been recently associated with pituitary adenomas. $m i R-15$ and $m i R-16$ have been shown to be strongly downregulated in these types of tumors. Their expression correlates with a greater tumor diameter and a lower p43 secretion, suggesting that these genes partially influence tumor growth (Bottoni et al. 2005). A recent study showed underexpression of miR-145, miR-21, miR-141, let-7a, miR-150, miR-15a, miR-16, and $m i R-143$ in ACTH-secreting pituitary tumors (Amaral et al. 2009). A decreased expression of let-7 was found in $42 \%$ of adenomas and was correlated with high-grade tumors. This miR inversely correlated with the highmobility group A2 protein expression, a factor most likely involved in the tumorigenesis of the pituitary gland (Qian et al. 2009).

\section{miRs and future treatment applications}

All cancers acquire the same set of functional capabilities during their development and progression, albeit through various mechanisms. To acquire a malignant phenotype, cells require a combination of diverse genetic abnormalities. Given the aforementioned associations of miRs with cancer development and progression, the peculiar and transversal appearance of miRs in these circuits, the multiplicity of their targets, and ability to control multiple pathways in parallel, it is now held that these small regulatory RNAs could serve as targets of new anticancer gene therapies. Inhibition of overexpressed miRs can be efficiently done with the use of sequencespecific antisense oligonucleotides, chemically modified (named antagomirs when cholesterol conjugated) to enhance stability and in vivo delivery 
(Meister et al. 2004, Krützfeldt et al. 2005). The rationale for using miRs as potential therapeutic targets comes from the many studies that have shown that specific miR deregulations (overexpression and downregulation) in cancer cells have a pathogenic effect (Tili et al. 2007).

For example, targeting the oncomiR-17-92 might be an effective tool for different neoplastic conditions (e.g. breast, adrenal, and thyroid cancers) that display overexpression of the cluster. Targeting miRs from the oncomiR-17-92 should affect more than one malignant capability, both inducing cell cycle arrest and apoptosis and suppressing the tumor's ability to sustain angiogenesis. The same should be obtained by re-expression of lost miRs, such as $m i R-15 a$ and $m i R$ 16 (ovarian, prostate, pancreatic, and pituitary tumors), which are known to act at the cell cycle arrest level, to induce apoptosis and block angiogenesis. The tumor xenograft model has proven to be successful with an overall reduction of tumor burden (Calin et al. 2008).

$m i R-21$ and $m i R-221 / 222$ clusters are often deregulated in several endocrine tumors (including breast, prostate, thyroid, liver, and pancreatic cancers), and they could represent other good target candidates for interference with survival signals, apoptosis, and metastasis.

$m i R-200$ and let-7 families (breast, ovarian, gastric, and prostate cancers) are certainly among the most attractive targets for several cancer therapies because of their complex regulatory network of cell program differentiation and their involvement in tumor progression. Importantly, due to its role in 'stemness' regulation, modulation of $m i R-200$ might significantly improve and sensitize cancer cells to treatments with existing chemotherapeutic agents. These classes of miRs undoubtedly deserve further studies.

Possible treatments for metastatic tumors could include reducing expression levels for $m i R-10 b$, $m i R-21, m i R-146$ family, $m i R-155, m i R-373$, and $m i R-520 \mathrm{c}$ in solid cancers by locked nucleic acid anti-miRs or antagomirs or re-expressing miR-126, $m i R-148 a, m i R-206, m i R-335$, and the $m i R-200$ family by mimic miRs. After preclinical studies (in vitro and in vivo), modulated miR expression could be applicable to Phase I clinical trials for cancer patients with advanced disease in combination with existing regimens. The appropriate and correct selection of patients based on miR profiling of the tumors becomes crucial in the context of a clinical trial using miR-targeted therapies. Only selected patients with specific ranges of expressions of miRs may exhibit optimal response.

Taking into account the multiple roles of miRs in cancer biology, disrupted miRs in cancer are dominant unifying players and not just an additional layer of complexity. There are clear opportunities for miR-based anticancer therapeutics. Diagnostic potentials for miRs have been identified, and we expect that clinical diagnostic trials will test their efficacy soon.

\section{Declaration of interest}

The authors declare that there is no conflict of interest that could be perceived as prejudicing the impartiality of the research reported.

\section{Funding}

G A Calin is supported as a Fellow at the University of Texas M. D. Anderson Research Trust, as a Fellow of the University of Texas System Regents Research Scholar, and by the Ladjevardian Regents Research Scholar Fund. This study was supported in part by a National Institutes of Health grant (1R01CA135444), by a Breast Cancer SPORE Developmental Award, and by an Ovarian Cancer SPORE Developmental Award.

L Santarpia is supported by Italian Association for Cancer Research (AIRC), American Thyroid Association (ATA ThyCa-Grant), Istituto Toscana Tumori (ITT), and Foundations Sandro Pitigliani and Carozza-Pollicino.

\section{Acknowledgements}

The authors are very thankful to Michael Worley for the editing of the manuscript.

\section{References}

Akao Y, Nakagawa Y \& Naoe T 2006 MicroRNAs 143 and 145 are possible common onco-microRNAs in human cancers. Oncology Reports 16 845-850.

Akao Y, Nakagawa Y \& Naoe T 2007 MicroRNA-143 and -145 in colon cancer. DNA and Cell Biology 26 311-320.

Amaral FC, Torres N, Saggioro F, Neder L, Machado HR, Silva WA Jr, Moreira AC \& Castro M 2009 MicroRNAs differentially expressed in ACTH-secreting pituitary tumors. Journal of Clinical Endocrinology and Metabolism 94 320-323.

Ambros V 2008 The evolution of our thinking about microRNAs. Nature Medicine 14 1036-1040.

Ambs S, Prueitt RL, Yi M, Hudson RS, Howe TM, Petrocca F, Wallace TA, Liu CG, Volinia S, Calin GA et al. 2008 Genomic profiling of microRNA and messenger RNA reveals deregulated microRNA expression in prostate cancer. Cancer Research 68 6162-6170.

Apte SM, Bucana CD, Killion JJ, Gershenson DM \& Fidler IJ 2004 Expression of platelet-derived growth factor and activated receptor in clinical specimens of epithelial ovarian cancer and ovarian carcinoma cell lines. Gynecologic Oncology 93 78-86. 
Asangani IA, Rasheed SA, Nikolova DA, Leupold JH, Colburn NH, Post S \& Allgayer H 2008 MicroRNA-21 (miR-21) post-transcriptionally downregulates tumor suppressor Pdcd4 and stimulates invasion, intravasation and metastasis in colorectal cancer. Oncogene 27 2128-2136.

Bailey SM, Brenneman MA \& Goodwin EH 2004 Frequent recombination in telomeric DNA may extend the proliferative life of telomerase-negative cells. Nucleic Acids Research 32 3743-3751.

Baldassarre G, Belletti B, Nicoloso MS, Schiappacassi M, Vecchione A, Spessotto P, Morrione A, Canzonieri V \& Colombatti A 2005 p27(Kip1)-stathmin interaction influences sarcoma cell migration and invasion. Cancer Cell 7 51-63.

Bandi N, Zbinden S, Gugger M, Arnold M, Kocher V, Hasan L, Kappeler A, Brunner T \& Vassella E 2009 miR-15a and miR-16 are implicated in cell cycle regulation in a $\mathrm{Rb}$-dependent manner and are frequently deleted or down-regulated in non-small cell lung cancer. Cancer Research $695553-5559$.

Bandres E, Bitarte N, Arias F, Agorreta J, Fortes P, Agirre X, Zarate R, Diaz-Gonzalez JA, Ramirez N, Sola JJ et al. 2009 microRNA-451 regulates macrophage migration inhibitory factor production and proliferation of gastrointestinal cancer cells. Clinical Cancer Research 15 2281-2290.

Bartek J \& Lukas J 2006 Cell biology. Balancing life-or-death decisions. Science 314 261-262.

Bartek J, Bartkova J \& Lukas J 2007 DNA damage signalling guards against activated oncogenes and tumour progression. Oncogene 26 7773-7779.

Benetti R, Gonzalo S, Jaco I, Muñoz P, Gonzalez S, Schoeftner S, Murchison E, Andl T, Chen T, Klatt P et al. 2008 A mammalian microRNA cluster controls DNA methylation and telomere recombination via Rbl2dependent regulation of DNA methyltransferases. Nature Structural and Molecular Biology 15 268-279.

Bhaumik D, Scott GK, Schokrpur S, Patil CK, Campisi J \& Benz CC 2008 Expression of microRNA-146 suppresses $\mathrm{NF}-\mathrm{kB}$ activity with reduction of metastatic potential in breast cancer cells. Oncogene 27 5643-5647.

Bjerkvig R, Tysnes BB, Aboody KS, Najbauer J \& Terzis AJ 2005 Opinion: the origin of the cancer stem cell: current controversies and new insights. Nature Reviews. Cancer 5 899-904.

Bloomston M, Frankel WL, Petrocca F, Volinia S, Alder H, Hagan JP, Liu CG, Bhatt D, Taccioli C \& Croce CM 2007 MicroRNA expression patterns to differentiate pancreatic adenocarcinoma from normal pancreas and chronic pancreatitis. Journal of the American Medical Association 297 1901-1908.

Bommer GT, Gerin I, Feng Y, Kaczorowski AJ, Kuick R, Love RE, Zhai Y, Giordano TJ, Qin ZS, Moore BB et al. 2007 p53-Mediated activation of miRNA34 candidate tumor-suppressor genes. Current Biology 17 1298-1307.
Bonci D, Coppola V, Musumeci M, Addario A, Giuffrida R, Memeo L, D'Urso L, Pagliuca A, Biffoni M, Labbaye C et al. 2008 The miR-15a-miR-16-1 cluster controls prostate cancer by targeting multiple oncogenic activities. Nature Medicine 14 1271-1277.

Bottoni A, Piccin D, Tagliati F, Luchin A, Zatelli MC \& degli Uberti EC 2005 miR-15a and miR-16-1 down-regulation in pituitary adenomas. Journal of Cellular Physiology 204 280-285.

Braun CJ, Zhang X, Savelyeva I, Wolff S, Moll UM, Schepeler T, Ørntoft TF, Andersen CL \& Dobbelstein M 2008 p53-Responsive microRNAs 192 and 215 are capable of inducing cell cycle arrest. Cancer Research 68 10094-10104.

Burk U, Schubert J, Wellner U, Schmalhofer O, Vincan E, Spaderna S \& Brabletz T 2008 A reciprocal repression between ZEB1 and members of the miR-200 family promotes EMT and invasion in cancer cells. EMBO Reports 9 582-589.

Calin GA \& Croce CM 2006 MicroRNA signatures in human cancers. Nature Reviews. Cancer 6 857-866.

Calin GA, Sevignani C, Dumitru CD, Hyslop T, Noch E, Yendamuri S, Shimizu M, Rattan S, Bullrich F, Negrini M et al. 2004 Human microRNA genes are frequently located at fragile sites and genomic regions involved in cancers. PNAS 101 2999-3004.

Calin GA, Cimmino A, Fabbri M, Ferracin M, Wojcik SE, Shimizu M, Taccioli C, Zanesi N, Garzon R, Aqeilan RI et al. $2008 \mathrm{MiR}-15 \mathrm{a}$ and miR-16-1 cluster functions in human leukemia. PNAS 105 5166-5171.

Campisi J 2005 Senescent cells, tumor suppression, and organismal aging: good citizens, bad neighbors. Cell 120 513-522.

Cao X, Pfaff SL \& Gage FH 2007 A functional study of miR-124 in the developing neural tube. Genes and Development 21 531-536.

Chambers AF, Groom AC \& MacDonald IC 2002 Dissemination and growth of cancer cells in metastatic sites. Nature Reviews. Cancer 2 563-572.

Chan JA, Krichevsky AM \& Kosik KS 2005 MicroRNA-21 is an antiapoptotic factor in human glioblastoma cells. Cancer Research 65 6029-6033.

Chang J, Nicolas E, Marks D, Sander C, Lerro A, Buendia MA, Xu C, Mason WS, Moloshok T, Bort R et al. 2004 miR-122, a mammalian liver-specific microRNA, is processed from her mRNA and may downregulate the high affinity cationic amino acid transporter CAT-1. RNA Biology 1 106-113.

Chang TC, Wentzel EA, Kent OA, Ramachandran K, Mullendore M, Lee KH, Feldmann G, Yamakuchi M, Ferlito M, Lowenstein CJ et al. 2007 Transactivation of miR-34a by p53 broadly influences gene expression and promotes apoptosis. Molecular Cell 26 745-752.

Chayka O, Corvetta D, Dews M, Caccamo AE, Piotrowska I, Santilli G, Gibson S, Sebire NJ, Himoudi N, Hogarty MD et al. 2009 Clusterin, a haploinsufficient tumor suppressor gene in neuroblastomas. Journal of the National Cancer Institute 101 663-677. 
Chen Y \& Gorski DH 2008 Regulation of angiogenesis through a microRNA (miR-130a) that down-regulates antiangiogenic homeobox genes GAX and HOXA5. Blood 111 1217-1226.

Chen RW, Bemis LT, Amato CM, Myint H, Tran H, Birks DK, Eckhardt SG \& Robinson WA 2008 Truncation in CCND1 mRNA alters miR-16-1 regulation in mantle cell lymphoma. Blood 112 822-829.

Chen X, Guo X, Zhang H, Xiang Y, Chen J, Yin Y, Cai X, Wang K, Wang G, Ba Y et al. 2009 Role of miR-143 targeting KRAS in colorectal tumorigenesis. Oncogene 28 1385-1392.

Chu IM, Hengst L \& Slingerland JM 2008 The Cdk inhibitor p27 in human cancer: prognostic potential and relevance to anticancer therapy. Nature Reviews. Cancer 8 253-267.

Cimmino A, Calin GA, Fabbri M, Iorio MV, Ferracin M, Shimizu M, Wojcik SE, Aqeilan RI, Zupo S, Dono M et al. $2005 \mathrm{miR}-15$ and miR-16 induce apoptosis by targeting BCL2. PNAS 102 13944-13949.

Cole KA, Attiyeh EF, Mosse YP, Laquaglia MJ, Diskin SJ, Brodeur GM \& Maris JM 2008 A functional screen identifies miR-34a as a candidate neuroblastoma tumour suppressor gene. Molecular Cancer Research 6 735-742.

Coller HA, Forman JJ \& Legesse-Miller A 2007 "Myc'ed messages": myc induces transcription of E2F1 while inhibiting its translation via a microRNA polycistron. PLoS Genetics 3 e146.

Corsten MF, Miranda R, Kasmieh R, Krichevsky AM, Weissleder R \& Shah K 2007 MicroRNA-21 knockdown disrupts glioma growth in vivo and displays synergistic cytotoxicity with neural precursor cell delivered S-TRAIL in human gliomas. Cancer Research 67 8994-9000.

Coulouarn C, Factor VM, Andersen JB, Durkin ME \& Thorgeirsson SS 2009 Loss of miR-122 expression in liver cancer correlates with suppression of the hepatic phenotype and gain of metastatic properties. Oncogene 28 3526-3536.

Dahiya N, Sherman-Baust CA, Wang TL, Davidson B, Shih IeM, Zhang Y, Wood W III, Becker KG \& Morin PJ 2008 MicroRNA expression and identification of putative miRNA targets in ovarian cancer. PLoS One 3 e2436.

Dews M, Homayouni A, Yu D, Murphy D, Sevignani C, Wentzel E, Furth EE, Lee WM, Enders GH, Mendell JT et al. 2006 Augmentation of tumor angiogenesis by a Myc-activated microRNA cluster. Nature Genetics $\mathbf{3 8}$ 1060-1065.

Dimri GP, Lee X, Basile G, Acosta M, Scott G, Roskelley C, Medrano EE, Linskens M, Rubelj I, Pereira-Smith O et al. 1995 A biomarker that identifies senescent human cells in culture and in aging skin in vivo. PNAS 92 9363-9367.

Du Y, Xu Y, Ding L, Yao H, Yu H, Zhou T \& Si J 2009 Down-regulation of miR-141 in gastric cancer and its involvement in cell growth. Journal of Gastroenterology 44 556-561.

Dutta KK, Zhong Y, Liu YT, Yamada T, Akatsuka S, Hu Q, Yoshihara M, Ohara H, Takehashi M, Shinohara T et al.
2007 Association of microRNA-34a overexpression with proliferation is cell type-dependent. Cancer Science $\mathbf{9 8}$ 1845-1852.

Eberhart JK, He X, Swartz ME, Yan YL, Song H, Boling TC, Kunerth AK, Walker MB, Kimmel CB \& Postlethwait JH 2008 MicroRNA Mirn140 modulates Pdgf signaling during palatogenesis. Nature Genetics 40 290-298.

Epis MR, Giles KM, Barker A, Kendrick TS \& Leedman PJ 2009 miR-331-3p regulates ERBB-2 expression and androgen receptor signaling in prostate cancer. Journal of Biological Chemistry 284 24696-24704.

Esquela-Kerscher A, Trang P, Wiggins JF, Patrawala L, Cheng A, Ford L, Weidhaas JB, Brown D, Bader AG \& Slack FJ 2008 The let-7 microRNA reduces tumor growth in mouse models of lung cancer. Cell Cycle 7 759-764.

Fasanaro P, D'Alessandra Y, Di Stefano V, Melchionna R, Romani S, Pompilio G, Capogrossi MC \& Martelli F 2008 MicroRNA-210 modulates endothelial cell response to hypoxia and inhibits the receptor tyrosine-kinase ligand Ephrin-A3. Journal of Biological Chemistry 283 15878-15883.

Fish JE, Santoro MM, Morton SU, Yu S, Yeh RF, Wythe JD, Ivey KN, Bruneau BG, Stainier DY \& Srivastava D 2008 miR-126 regulates angiogenic signaling and vascular integrity. Developmental Cell 15 272-284.

Foekens JA, Sieuwerts AM, Smid M, Look MP, de Weerd V, Boersma AW, Klijn JG, Wiemer EA \& Martens JW 2008 Four miRNAs associated with aggressiveness of lymphnode-negative, estrogen receptor-positive human breast cancer. PNAS 105 13021-13026.

Fontana L, Fiori ME, Albini S, Cifaldi L, Giovinazzi S, Forloni M, Boldrini R, Donfrancesco A, Federici V, Giacomini P et al. 2008 Antagomir-17-5p abolishes the growth of therapy-resistant neuroblastoma through p21 and BIM. PLoS One 3 e2236.

Fornari F, Gramantieri L, Ferracin M, Veronese A, Sabbioni S, Calin GA, Grazi GL, Giovannini C, Croce CM, Bolondi L et al. 2008 MiR-221 controls CDKN1C/p57 and CDKN1B/p27 expression in human hepatocellular carcinoma. Oncogene 27 5651-5661.

Fornari F, Gramantieri L, Giovannini C, Veronese A, Ferracin M, Sabbioni S, Calin GA, Grazi GL, Croce CM, Tavolari S et al. 2009 MiR-122/cyclin G1 interaction modulates p53 activity and affects doxorubicin sensitivity of human hepatocarcinoma cells. Cancer Research 69 5761-5767.

Frankel LB, Christoffersen NR, Jacobsen A, Lindow M, Krogh A \& Lund AH 2008 Programmed cell death 4 (PDCD4) is an important functional target of the microRNA miR-21 in breast cancer cells. Journal of Biological Chemistry 283 1026-1033.

Friedl P 2004 Prespecification and plasticity: shifting mechanisms of cell migration. Current Opinion in Cell Biology 16 14-23.

Friedl P \& Wolf K 2003 Tumour-cell invasion and migration: diversity and escape mechanisms. Nature Reviews. Cancer 3 362-374. 
Galardi S, Mercatelli N, Giorda E, Massalini S, Frajese GV, Ciafrè SA \& Farace MG 2007 miR-221 and miR-222 expression affects the proliferation potential of human prostate carcinoma cell lines by targeting p27Kip1. Journal of Biological Chemistry 282 23716-23724.

Gandellini P, Folini M, Longoni N, Pennati M, Binda M, Colecchia M, Salvioni R, Supino R, Moretti R, Limonta P et al. 2009 miR-205 exerts tumor-suppressive functions in human prostate through down-regulation of protein kinase Cepsilon. Cancer Research 69 2287-2295.

Georges SA, Biery MC, Kim SY, Schelter JM, Guo J, Chang AN, Jackson AL, Carleton MO, Linsley PS, Cleary MA et al. 2008 Coordinated regulation of cell cycle transcripts by 53-inducible microRNAs, miR-192 and miR-215.

Cancer Research 68 10105-10112.

Gironella M, Seux M, Xie MJ, Cano C, Tomasini R, Gommeaux J, Garcia S, Nowak J, Yeung ML, Jeang KT et al. 2007 Tumor protein 53-induced nuclear protein 1 expression is repressed by miR-155, and its restoration inhibits pancreatic tumor development. PNAS 104 16170-16175.

Gorski DH \& Walsh K 2003 Control of vascular cell differentiation by homeobox transcription factors. Trends in Cardiovascular Medicine 13 213-220.

Gramantieri L, Ferracin M, Fornari F, Veronese A, Sabbioni S, Liu CG, Calin GA, Giovannini C, Ferrazzi E, Grazi GL et al. 2007 Cyclin $\mathrm{G}_{1}$ is a target of miR-122a, a microRNA frequently down-regulated in human hepatocellular carcinoma. Cancer Research $\mathbf{6 7}$ 6092-6099.

Gramantieri L, Fornari F, Callegari E, Sabbioni S, Lanza G, Croce CM, Bolondi L \& Negrini M 2008 MicroRNA involvement in hepatocellular carcinoma. Journal of Cellular and Molecular Medicine 12 2189-2204.

Gregory PA, Bert AG, Paterson EL, Barry SC, Tsykin A, Farshid G, Vadas MA, Khew-Goodall Y \& Goodall GJ 2008 The miR-200 family and miR-205 regulate epithelial to mesenchymal transition by targeting ZEB1 and SIP1. Nature Cell Biology 10 593-601.

Grinstein E \& Wernet P 2007 Cellular signaling in normal and cancerous stem cells. Cell Signalling 19 2428-2433.

Guo W, Pylayeva Y, Pepe A, Yoshioka T, Muller WJ, Inghirami G \& Giancotti FG 2006 Beta 4 integrin amplifies ErbB2 signaling to promote mammary tumorigenesis. Cell 126 489-502.

Guo C, Sah JF, Beard L, Willson JK, Markowitz SD \& Guda K $2008 a$ The noncoding RNA, miR-126, suppresses the growth of neoplastic cells by targeting phosphatidylinositol 3-kinase signaling and is frequently lost in colon cancers. Genes, Chromosomes \& Cancer 47 939-946.

Hanahan D \& Weinberg RA 2000 The hallmarks of cancer. Cell 100 57-70.

He L, Thomson JM, Hemann MT, Hernando-Monge E, Mu D, Goodson S, Powers S, Cordon-Cardo C, Lowe SW, Hannon GJ et al. 2005 a A microRNA polycistron as a potential human oncogene. Nature 435 828-833.
He H, Jazdzewski K, Li W, Liyanarachchi S, Nagy R, Volinia S, Calin GA, Liu CG, Franssila K, Suster S et al. $2005 b$ The role of microRNA genes in papillary thyroid carcinoma. PNAS 102 19075-19080.

He L, He X, Lim LP, de Stanchina E, Xuan Z, Liang Y, Xue W, Zender L, Magnus J, Ridzon D et al. 2007 A microRNA component of the p53 tumour suppressor network. Nature 447 1130-1134.

Heaney AP \& Melmed S 2005 Oncogenes and Tumor Suppressor Genes in Tumorigenesis of the Endocrine System. In Endocrinology: Basic and Clinical Principles. Eds S Melmed \& MP Conn, 2nd Edn, pp 301-309. Humana Press: Heidelberg, Germany.

Heldin CH, Landström M \& Moustakas A 2009 Mechanism of TGF-beta signaling to growth arrest, apoptosis, and epithelial-mesenchymal transition. Current Opinion in Cell Biology 21 166-176.

Hermeking H 2009 The miR-34 family in cancer and apoptosis. Cell Death and Differentiation (Epub ahead of print).

Hiyoshi Y, Kamohara H, Karashima R, Sato N, Imamura Y, Nagai Y, Yoshida N, Toyama E, Hayashi N, Watanabe M et al. 2009 MicroRNA-21 regulates the proliferation and invasion in esophageal squamous cell carcinoma. Clinical Cancer Research 15 1915-1922.

Hornstein E \& Shomron N 2006 Canalization of development by microRNAs. Nature Genetics 38 (Suppl) S20-S24.

Hua Z, Lv Q, Ye W, Wong CK, Cai G, Gu D, Ji Y, Zhao C, Wang J, Yang BB et al. 2006 MiRNA-directed regulation of VEGF and other angiogenic factors under hypoxia. PLoS One 1 e116.

Huang Q, Gumireddy K, Schrier M, le Sage C, Nagel R, Nair S, Egan DA, Li A, Huang G, Klein-Szanto AJ et al. 2008 The microRNAs miR-373 and miR-520c promote tumour invasion and metastasis. Nature Cell Biology 10 202-210.

Huang TH, Wu F, Loeb GB, Hsu R, Heidersbach A, Brincat A, Horiuchi D, Lebbink RJ, Mo YY, Goga A et al. 2009 Up-regulation of miR-21 by HER2/neu signaling promotes cell invasion. Journal of Biological Chemistry 284 18515-18524.

Hurteau GJ, Carlson JA, Spivack SD \& Brock GJ 2007 Overexpression of the microRNA hsa-miR-200c leads to reduced expression of transcription factor 8 and increased expression of E-cadherin. Cancer Research 67 7972-7976.

Iaquinta PJ \& Lees JA 2007 Life and death decisions by the E2F transcription factors. Current Opinion in Cell Biology 19 649-657.

Iliopoulos D, Bimpaki EI, Nesterova M \& Stratakis CA 2009 MicroRNA signature of primary pigmented nodular adrenocortical disease: clinical correlations and regulation of Wnt signaling. Cancer Research 69 3278-3282.

Iorio MV, Ferracin M, Liu CG, Veronese A, Spizzo R, Sabbioni S, Magri E, Pedriali M, Fabbri M, Campiglio M et al. 2005 MicroRNA gene expression deregulation in human breast cancer. Cancer Research 65 7065-7070. 
Iorio MV, Visone R, Di Leva G, Donati V, Petrocca F, Casalini P, Taccioli C, Volinia S, Liu CG, Alder $\mathrm{H}$ et al. 2007 MicroRNA signatures in human ovarian cancer. Cancer Research 67 8699-8707.

Iorio MV, Casalini P, Tagliabue E, Ménard S \& Croce CM 2008 MicroRNA profiling as a tool to understand prognosis, therapy response and resistance in breast cancer. European Journal of Cancer 44 2753-2759.

Iorio MV, Casalini P, Piovan C, Di Leva G, Merlo A, Triulzi T, Ménard S, Croce CM \& Tagliabue E 2009 microRNA205 regulates HER3 in human breast cancer. Cancer Research 69 2195-2200.

Jazdzewski K, Murray EL, Franssila K, Jarzab B, Schoenberg DR \& de la Chapelle A 2008 Common SNP in pre-miR146 a decreases mature miR expression and predisposes to papillary thyroid carcinoma. PNAS 105 7269-7274.

Jazdzewski K, Liyanarachchi S, Swierniak M, Pachucki J, Ringel MD, Jarzab B \& de la Chapelle A 2009 Polymorphic mature microRNAs from passenger strand of pre-miR146a contribute to thyroid cancer. PNAS 106 1502-1505.

Jiang J, Lee EJ, Gusev Y \& Schmittgen TD 2005 Real-time expression profiling of microRNA precursors in human cancer cell lines. Nucleic Acids Research 33 5394-5403.

Johnson SM, Grosshans H, Shingara J, Byrom M, Jarvis R, Cheng A, Labourier E, Reinert KL, Brown D \& Slack FJ 2005 RAS is regulated by the let-7 microRNA family. Cell 120 635-647.

Jopling CL, Yi M, Lancaster AM, Lemon SM \& Sarnow P 2005 Modulation of hepatitis C virus RNA abundance by a liver-specific microRNA. Science 309 1577-1581.

Kim VN 2005 MicroRNA biogenesis: coordinated cropping and dicing. Nature Reviews. Molecular Cell Biology 6 376-385.

Kim JW, Wong CW, Goldsmith JD, Song C, Fu W, Allion MB, Herlyn M, Al-Mehdi AB \& Muschel RJ 2004 Rapid apoptosis in the pulmonary vasculature distinguishes nonmetastatic from metastatic melanoma cells. Cancer Letters 213 203-212.

Kim HH, Kuwano Y, Srikantan S, Lee EK, Martindale JL \& Gorospe M 2009 HuR recruits let-7/RISC to repress c-Myc expression. Genes and Development 23 1743-1748.

Kong W, Yang H, He L, Zhao JJ, Coppola D, Dalton WS \& Cheng JQ 2008 MicroRNA-155 is regulated by the transforming growth factor beta/Smad pathway and contributes to epithelial cell plasticity by targeting RhoA. Molecular and Cellular Biology 28 6773-6784.

Kong D, Li Y, Wang Z, Banerjee S, Ahmad A, Kim HR \& Sarkar FH 2009 miR-200 regulates PDGF-D-mediated epithelial-mesenchymal transition, adhesion, and invasion of prostate cancer cells. Stem Cells $\mathbf{2 7}$ 1712-1721.

Korpal M, Lee ES, Hu G \& Kang Y 2008 The miR-200 family inhibits epithelial-mesenchymal transition and cancer cell migration by direct targeting of E-cadherin transcriptional repressors ZEB1 and ZEB2. Journal of Biological Chemistry 283 14910-14914.
Kota J, Chivukula RR, O’Donnell KA, Wentzel EA, Montgomery CL, Hwang HW, Chang TC, Vivekanandan P, Torbenson M, Clark KR et al. 2009 Therapeutic microRNA delivery suppresses tumorigenesis in a murine liver cancer model. Cell 137 1005-1017.

Krützfeldt J, Rajewsky N, Braich R, Rajeev KG, Tuschl T, Manoharan M \& Stoffel M 2005 Silencing of microRNAs in vivo with 'antagomirs'. Nature 438 685-689.

Kuehbacher A, Urbich C, Zeiher AM \& Dimmeler S 2007 Role of Dicer and Drosha for endothelial microRNA expression and angiogenesis. Circulation Research 101 59-68.

Kulshreshtha R, Ferracin M, Wojcik SE, Garzon R, Alder H, Agosto-Perez FJ, Davuluri R, Liu CG, Croce CM, Negrini M et al. 2007 A microRNA signature of hypoxia. Molecular and Cellular Biology 27 1859-1867.

Kumamoto K, Spillare EA, Fujita K, Horikawa I, Yamashita T, Appella E, Nagashima M, Takenoshita S, Yokota J \& Harris CC 2008 Nutlin-3a activates p53 to both downregulate inhibitor of growth 2 and up-regulate mir-34a, mir-34b, and mir-34c expression, and induce senescence. Cancer Research 68 3193-3203.

Kumar MS, Erkeland SJ, Pester RE, Chen CY, Ebert MS, Sharp PA \& Jacks T 2008 Suppression of non-small cell lung tumor development by the let-7 microRNA family. PNAS 105 3903-3908.

Laneve P, Di Marcotullio L, Gioia U, Fiori ME, Ferretti E, Gulino A, Bozzoni I \& Caffarelli E 2007 The interplay between microRNAs and the neurotrophin receptor tropomyosin-related kinase $\mathrm{C}$ controls proliferation of human neuroblastoma cells. PNAS 104 7957-7962.

Lee YS \& Dutta A 2007 The tumor suppressor microRNA let-7 represses the HMGA2 oncogene. Genes and Development 21 1025-1030.

Lee KH, Chen YL, Yeh SD, Hsiao M, Lin JT, Goan YG \& Lu PJ 2009 MicroRNA-330 acts as tumor suppressor and induces apoptosis of prostate cancer cells through E2F1-mediated suppression of Akt phosphorylation. Oncogene 28 3360-3370.

Letai AG 2008 Diagnosing and exploiting cancer's addiction to blocks in apoptosis. Nature Reviews. Cancer $\mathbf{8}$ 121-132.

Li N, Fu H, Tie Y, Hu Z, Kong W, Wu Y \& Zheng X $2009 a$ miR-34a inhibits migration and invasion by down-regulation of c-Met expression in human hepatocellular carcinoma cells. Cancer Letters 275 44-53.

Li T, Li D, Sha J, Sun P \& Huang Y $2009 b$ MicroRNA-21 directly targets MARCKS and promotes apoptosis resistance and invasion in prostate cancer cells. Biochemical and Biophysical Research Communications 383 280-285.

Lin SL, Chiang A, Chang D \& Ying SY 2008 Loss of mir-146a function in hormone-refractory prostate cancer. RNA 14 417-424. 
Linsley PS, Schelter J, Burchard J, Kibukawa M, Martin MM, Bartz SR, Johnson JM, Cummins JM, Raymond CK, Dai H et al. 2007 Transcripts targeted by the microRNA-16 family cooperatively regulate cell cycle progression. Molecular and Cellular Biology 27 2240-2252.

Löffler D, Brocke-Heidrich K, Pfeifer G, Stocsits C, Hackermüller J, Kretzschmar AK, Burger R, Gramatzki M, Blumert C, Bauer K et al. 2007 Interleukin-6 dependent survival of multiple myeloma cells involves the Stat3-mediated induction of microRNA-21 through a highly conserved enhancer. Blood 110 1330-1333.

Loureiro RM \& D’Amore PA 2005 Transcriptional regulation of vascular endothelial growth factor in cancer. Cytokine and Growth Factor Reviews 16 77-89.

Lu J, Getz G, Miska EA, Alvarez-Saavedra E, Lamb J, Peck D, Sweet-Cordero A, Ebert BL, Mak RH, Ferrando AA et al. 2005 MicroRNA expression profiles classify human cancers. Nature 435 834-838.

Lu Z, Liu M, Stribinskis V, Klinge CM, Ramos KS, Colburn NH \& Li Y 2008 MicroRNA-21 promotes cell transformation by targeting the programmed cell death 4 gene. Oncogene 27 4373-4379.

Lujambio A \& Esteller M 2007 CpG island hypermethylation of tumor suppressor microRNAs in human cancer. Cell Cycle 6 1455-1459.

Lujambio A, Calin GA, Villanueva A, Ropero S, SánchezCéspedes M, Blanco D, Montuenga LM, Rossi S, Nicoloso MS, Faller WJ et al. 2008 A microRNA DNA methylation signature for human cancer metastasis. PNAS 105 13556-13561.

Ma L, Teruya-Feldstein J \& Weinberg RA 2007 Tumour invasion and metastasis initiated by microRNA-10b in breast cancer. Nature 449 682-688.

Marhaba R \& Zoller M 2004 CD44 in cancer progression: adhesion, migration and growth regulation. Journal of Molecular Histology 35 211-231.

Marhaba R, Klingbeil P, Nuebel T, Nazarenko I, Buechler MW \& Zoeller M 2008 CD44 and EpCAM: cancerinitiating cell markers. Current Molecular Medicine $\mathbf{8}$ 784-804.

Mayr C, Hemann MT \& Bartel DP 2007 Disrupting the pairing between let-7 and Hmga2 enhances oncogenic transformation. Science 315 1576-1579.

Mees ST, Mardin WA, Wendel C, Baeumer N, Willscher E, Senninger N, Schleicher C, Colombo-Benkmann M \& Haier J 2009a EP300 - a miRNA-regulated metastasis suppressor gene in ductal adenocarcinomas of the pancreas. International Journal of Cancer 126 114-124.

Mees ST, Mardin WA, Sielker S, Willscher E, Senninger N, Schleicher C, Colombo-Benkmann M \& Haier J 2009b Involvement of CD40 targeting miR-224 and miR-486 on the progression of pancreatic ductal adenocarcinomas. Annals of Surgical Oncology 16 2339-2350.

Meister G, Landthaler M, Dorsett Y \& Tuschl T 2004 Sequence-specific inhibition of microRNA- and siRNAinduced RNA silencing. RNA 10 544-550.
Meng F, Henson R, Lang M, Wehbe H, Maheshwari S, Mendell JT, Jiang J, Schmittgen TD \& Patel T 2006 Involvement of human micro-RNA in growth and response to chemotherapy in human cholangiocarcinoma cell lines. Gastroenterology 130 2113-2129.

Meng F, Henson R, Wehbe-Janek H, Ghoshal K, Jacob ST \& Patel T 2007 MicroRNA-21 regulates expression of the PTEN tumor suppressor gene in human hepatocellular cancer. Gastroenterology 133 647-658.

Mertens-Talcott SU, Chintharlapalli S, Li X \& Safe S 2007 The oncogenic microRNA-27a targets genes that regulate specificity protein transcription factors and the G2-M checkpoint in MDA-MB-231 breast cancer cells. Cancer Research 67 11001-11011.

Michael MZ, O'Connor SM, van Holst Pellekaan NG, Young GP \& James RJ 2003 Reduced accumulation of specific microRNAs in colorectal neoplasia. Molecular Cancer Research 1 882-891.

Migliore C, Petrelli A, Ghiso E, Corso S, Capparuccia L, Eramo A, Comoglio PM \& Giordano S 2008 MicroRNAs impair MET-mediated invasive growth. Cancer Research 68 10128-10136.

Mitomo S, Maesawa C, Ogasawara S, Iwaya T, Shibazaki M, Yashima-Abo A, Kotani K, Oikawa H, Sakurai E, Izutsu $\mathrm{N}$ et al. 2008 Downregulation of miR-138 is associated with overexpression of human telomerase reverse transcriptase protein in human anaplastic thyroid carcinoma cell lines. Cancer Science 99 280-286.

Miura N, Sato R, Tsukamoto T, Shimizu M, Kabashima H, Takeda M, Takahashi S, Harada T, West JE, Drabkin H et al. 2009 A noncoding RNA gene on chromosome 10p15.3 may function upstream of hTERT. BMC Molecular Biology 105.

Moasser MM 2007 The oncogene HER2: its signaling and transforming functions and its role in human cancer pathogenesis. Oncogene 26 6469-6487.

Motoyama K, Inoue H, Nakamura Y, Uetake H, Sugihara K \& Mori M 2008 Clinical significance of high mobility group A2 in human gastric cancer and its relationship to let-7 microRNA family. Clinical Cancer Research 14 2334-2340.

Nam EJ, Yoon H, Kim SW, Kim H, Kim YT, Kim JH, Kim JW \& Kim S 2008 MicroRNA expression profiles in serous ovarian carcinoma. Clinical Cancer Research 14 2690-2695.

Nicoloso MS, Spizzo R, Shimizu M, Rossi S \& Calin GA 2009 MicroRNAs - the micro steering wheel of tumour metastases. Nature Reviews. Cancer 9 293-302.

Nikiforova MN, Tseng GC, Steward D, Diorio D \& Nikiforov YE 2008 MicroRNA expression profiling of thyroid tumors: biological significance and diagnostic utility. Journal of Clinical Endocrinology and Metabolism 93 1600-1608.

Noonan EJ, Place RF, Pookot D, Basak S, Whitson JM, Hirata H, Giardina C \& Dahiya R 2009 miR-449a targets HDAC-1 and induces growth arrest in prostate cancer. Oncogene 28 1714-1724. 
O’Connell RM, Taganov KD, Boldin MP, Cheng G \& Baltimore D 2007 MicroRNA-155 is induced during the macrophage inflammatory response. PNAS 104 1604-1609.

O’Donnell KA, Wentzel EA, Zeller KI, Dang CV \& Mendell JT 2005 c-Myc-regulated microRNAs modulate E2F1 expression. Nature 435 839-843.

Ovcharenko D, Kelnar K, Johnson C, Leng N \& Brown D 2007 Genome-scale microRNA and small interfering RNA screens identify small RNA modulators of TRAILinduced apoptosis pathway. Cancer Research $\mathbf{6 7}$ 10782-10788.

Ozen M, Creighton CJ, Ozdemir M \& Ittmann M 2007 Widespread deregulation of microRNA expression in human prostate cancer. Oncogene 27 1788-1793.

Pallante P, Visone R, Ferracin M, Ferraro A, Berlingieri MT, Troncone G, Chiappetta G, Liu CG, Santoro M, Negrini M et al. 2006 MicroRNA deregulation in human thyroid papillary carcinomas. Endocrine-Related Cancer 13 497-508.

Park SM, Shell S, Radjabi AR, Schickel R, Feig C, Boyerinas B, Dinulescu DM, Lengyel E \& Peter ME 2007 Let-7 prevents early cancer progression by suppressing expression of the embryonic gene HMGA2. Cell Cycle 6 2585-2590.

Park SM, Gaur AB, Lengyel E \& Peter ME 2008 The miR-200 family determines the epithelial phenotype of cancer cells by targeting the E-cadherin repressors ZEB1 and ZEB2. Genes and Development 22 894-907.

Peinado H, Olmeda D \& Cano A 2007 Snail, Zeb and bHLH factors in tumour progression: an alliance against the epithelial phenotype? Nature Reviews. Cancer 7 415-428.

Peter ME 2009 Let-7 and miR-200 microRNAs: guardians against pluripotency and cancer progression. Cell Cycle $\mathbf{8}$ 843-852.

Petrocca F, Visone R, Onelli MR, Shah MH, Nicoloso MS, de Martino I, Iliopoulos D, Pilozzi E, Liu CG, Negrini M et al. 2008 E2F1-regulated microRNAs impair TGFbetadependent cell-cycle arrest and apoptosis in gastric cancer. Cancer Cell 13 272-286.

Pezzolesi MG, Platzer P, Waite KA \& Eng C 2008 Differential expression of PTEN-targeting microRNAs miR-19a and miR-21 in Cowden syndrome. American Journal of Human Genetics 82 1141-1149.

Place RF, Li LC, Pookot D, Noonan EJ \& Dahiya R 2008 MicroRNA-373 induces expression of genes with complementary promoter sequences. PNAS 105 1608-1613.

Ponta H, Sherman L \& Herrlich PA 2003 CD44: from adhesion molecules to signalling regulators. Nature Reviews. Molecular Cell Biology 4 33-45.

Porkka KP, Pfeiffer MJ, Waltering KK, Vessella RL, Tammela TL \& Visakorpi T 2007 MicroRNA expression profiling in prostate cancer. Cancer Research 67 6130-6135.

Qian ZR, Asa SL, Siomi H, Siomi MC, Yoshimoto K, Yamada S, Wang EL, Rahman MM, Inoue H, Itakura M et al. 2009 Overexpression of HMGA2 relates to reduction of the let-7 and its relationship to clinicopathological features in pituitary adenomas. Modern Pathology 22 431-441.

Raver-Shapira N, Marciano E, Meiri E, Spector Y, Rosenfeld N, Moskovits N, Bentwich Z \& Oren M 2007 Transcriptional activation of miR-34a contributes to p53-mediated apoptosis. Molecular Cell 26 731-743.

Rigoutsos I 2009 New tricks for animal microRNAS: targeting of amino acid coding regions at conserved and nonconserved sites. Cancer Research 69 3245-3248.

Romero DG, Plonczynski MW, Carvajal CA, GomezSanchez EP \& Gomez-Sanchez CE 2008 Microribonucleic acid-21 increases aldosterone secretion and proliferation in H295R human adrenocortical cells. Endocrinology 149 2477-2483.

le Sage C, Nagel R, Egan DA, Schrier M, Mesman E, Mangiola A, Anile C, Maira G, Mercatelli N, Ciafrè SA et al. 2007 Regulation of the p27(Kip1) tumor suppressor by miR-221 and miR-222 promotes cancer cell proliferation. EMBO Journal 26 3699-3708.

Sahai E 2007 Illuminating the metastatic process. Nature Reviews. Cancer 7 737-749.

Saito Y, Liang G, Egger G, Friedman JM, Chuang JC, Coetzee GA \& Jones PA 2006 Specific activation of microRNA-127 with downregulation of the protooncogene BCL6 by chromatin-modifying drugs in human cancer cells. Cancer Cell 9 435-443.

Salvi A, Sabelli C, Moncini S, Venturin M, Arici B, Riva P, Portolani N, Giulini SM, De Petro G \& Barlati S 2009 MicroRNA-23b mediates urokinase and c-met downmodulation and a decreased migration of human hepatocellular carcinoma cells. FEBS Journal 276 2966-2982.

Sampson VB, Rong NH, Han J, Yang Q, Aris V, Soteropoulos P, Petrelli NJ, Dunn SP \& Krueger LJ 2007 MicroRNA let-7a down-regulates MYC and reverts MYC-induced growth in Burkitt lymphoma cells. Cancer Research 67 9762-9770.

Schulte JH, Horn S, Otto T, Samans B, Heukamp LC, Eilers UC, Krause M, Astrahantseff K, Klein-Hitpass L, Buettner R et al. 2008 MYCN regulates oncogenic MicroRNAs in neuroblastoma. International Journal of Cancer 122 699-704.

Scott GK, Goga A, Bhaumik D, Berger CE, Sullivan CS \& Benz CC 2007 Coordinate suppression of ERBB2 and ERBB3 by enforced expression of micro-RNA miR-125a or miR-125b. Journal of Biological Chemistry 282 1479-1486.

Semenza GL 2000 HIF-1: using two hands to flip the angiogenic switch. Cancer Metastasis Reviews 19 59-65.

Semenza GL 2003 Angiogenesis in ischemic and neoplastic disorders. Annual Review of Medicine 54 17-28.

Sempere LF, Christensen M, Silahtaroglu A, Bak M, Heath CV, Schwartz G, Wells W, Kauppinen S \& Cole CN 2007 
Altered microRNA expression confined to specific epithelial cell subpopulations in breast cancer. Cancer Research 67 11612-11620.

Sengupta S, den Boon JA, Chen IH, Newton MA, Stanhope SA, Cheng YJ, Chen CJ, Hildesheim A, Sugden B \& Ahlquist P 2008 MicroRNA 29c is down-regulated in nasopharyngeal carcinomas, up-regulating mRNAs encoding extracellular matrix proteins. PNAS $\mathbf{1 0 5} 5874-5878$.

Seux M, Iovanna J, Dagorn JC \& Dusetti NJ 2009 MicroRNAs in pancreatic ductal adenocarcinoma: new diagnostic and therapeutic clues. Pancreatology 9 66-72.

Shell S, Park SM, Radjabi AR, Schickel R, Kistner EO, Jewell DA, Feig C, Lengyel E \& Peter ME 2007 Let-7 expression defines two differentiation stages of cancer. PNAS 104 11400-11405.

Sheu SY, Grabellus F, Schwertheim S, Handke S, Worm K \& Schmid KW 2009 Lack of correlation between BRAF V600E mutational status and the expression profile of a distinct set of miRNAs in papillary thyroid carcinoma. Hormone and Metabolic Research 41 482-487.

Shi M \& Guo N 2009 MicroRNA expression and its implications for the diagnosis and therapeutic strategies of breast cancer. Cancer Treatment Reviews 35 328-334.

Shi B, Sepp-Lorenzino L, Prisco M, Linsley P, deAngelis T \& Baserga R 2007 MicroRNA 145 targets the insulin receptor substrate-1 and inhibits the growth of colon cancer cells. Journal of Biological Chemistry 282 32582-32590.

Shimono Y, Zabala M, Cho RW, Lobo N, Dalerba P, Qian D, Diehn M, Liu H, Panula SP, Chiao E et al. 2009 Downregulation of miRNA-200c links breast cancer stem cells with normal stem cells. Cell 138 592-603.

Si ML, Zhu S, Wu H, Lu Z, Wu F \& Mo YY 2007 miR-21-mediated tumor growth. Oncogene 26 2799-2803.

Silber J, Lim DA, Petritsch C, Persson AI, Maunakea AK, Yu M, Vandenberg SR, Ginzinger DG, James CD, Costello JF et al. 2008 miR-124 and miR-137 inhibit proliferation of glioblastoma multiforme cells and induce differentiation of brain tumor stem cells. BMC Medicine 614 .

Spahn M, Kneitz S, Scholz CJ, Nico S, Rüdiger T, Ströbel P, Riedmiller H \& Kneitz B 2009 Expression of microRNA221 is progressively reduced in aggressive prostate cancer and metastasis and predicts clinical recurrence. International Journal of Cancer [in press].

Spizzo R, Nicoloso MS, Croce CM \& Calin GA 2009 SnapShot: microRNAs in cancer. Cell 137 586-586e1.

Stewart SA \& Weinberg RA 2000 Telomerase and human tumorigenesis. Seminars in Cancer Biology 10 399-406.

Su H, Yang JR, Xu T, Huang J, Xu L, Yuan Y \& Zhuang SM 2009 MicroRNA-101, down-regulated in hepatocellular carcinoma, promotes apoptosis and suppresses tumorigenicity. Cancer Research 69 1135-1142.

Suárez Y, Fernández-Hernando C, Pober JS \& Sessa WC 2007 Dicer dependent microRNAs regulate gene expression and functions in human endothelial cells. Circulation Research 100 1164-1173.
Sun F, Fu H, Liu Q, Tie Y, Zhu J, Xing R, Sun Z \& Zheng X 2008 Downregulation of CCND1 and CDK6 by miR-34a induces cell cycle arrest. FEBS Letters 582 1564-1568.

Sylvestre Y, De Guire V, Querido E, Mukhopadhyay UK, Bourdeau V, Major F, Ferbeyre G \& Chartrand P 2007 An E2F/miR-20a autoregulatory feedback loop. Journal of Biological Chemistry 282 2135-2143.

Szafranska AE, Davison TS, John J, Cannon T, Sipos B, Maghnouj A, Labourier E \& Hahn SA 2007 MicroRNA expression alterations are linked to tumorigenesis and non-neoplastic processes in pancreatic ductal adenocarcinoma. Oncogene 26 4442-4452.

Takagi T, Iio A, Nakagawa Y, Naoe T, Tanigawa N \& Akao Y 2009 Decreased expression of microRNA-143 and -145 in human gastric cancers. Oncology 77 12-21.

Takakura S, Mitsutake N, Nakashima M, Namba H, Saenko VA, Rogounovitch TI, Nakazawa Y, Hayashi T, Ohtsuru A \& Yamashita S 2008 Oncogenic role of miR-17-92 cluster in anaplastic thyroid cancer cells. Cancer Science 99 1147-1154.

Tanaka S, Sugimachi K, Yamashita Y, Shirabe K, Shimada M, Wands JR \& Sugimachi K 2003 Angiogenic switch as a molecular target of malignant tumors. Journal of Gastroenterology 38 (Suppl 15) 93-97.

Tavazoie SF, Alarcón C, Oskarsson T, Padua D, Wang Q, Bos PD, Gerald WL \& Massagué J 2008 Endogenous human microRNAs that suppress breast cancer metastasis. Nature 451 147-152.

Tazawa H, Tsuchiya N, Izumiya M \& Nakagama H 2007 Tumor-suppressive miR-34a induces senescence-like growth arrest through modulation of the E2F pathway in human colon cancer cells. PNAS 104 15472-15477.

Tchernitsa OI, Sers C, Zuber J, Hinzmann B, Grips M, Schramme A, Lund P, Schwendel A, Rosenthal A \& Schäfer R 2004 Transcriptional basis of KRAS oncogenemediated cellular transformation in ovarian epithelial cells. Oncogene 23 4536-4555.

Thuault S, Tan EJ, Peinado H, Cano A, Heldin CH \& Moustakas A 2008 HMGA2 and Smads co-regulate SNAIL1 expression during induction of epithelialto-mesenchymal transition. Journal of Biological Chemistry 283 33437-33446.

Tili E, Michaille JJ, Gandhi V, Plunkett W, Sampath D \& Calin GA 2007 miRNAs and their potential for use against cancer and other diseases. Future Oncology 3 521-537.

Tömböl Z, Szabó P, Molnár V, Wiener Z, Tölgyesi G, Horànyi J, Riesz P, Reismann P, Patócs A, Likó I et al. 2009 Integrative molecular-bioinformatics study of human adrenocortical tumors: microRNA, tissue specific target prediction and pathway analysis. EndocrineRelated Cancer 16 895-906.

Tsang J, Zhu J \& van Oudenaarden A 2007 MicroRNAmediated feedback and feedforward loops are recurrent network motifs in mammals. Molecular Cell 26 $753-767$. 
Valastyan S, Reinhardt F, Benaich N, Calogrias D, Szász AM, Wang ZC, Brock JE, Richardson AL \& Weinberg RA 2009 A pleiotropically acting microRNA, miR-31, inhibits breast cancer metastasis. Cell 137 1032-1046.

Varambally S, Cao Q, Mani RS, Shankar S, Wang X, Ateeq B, Laxman B, Cao X, Jing X, Ramnarayanan K et al. 2008 Genomic loss of microRNA-101 leads to overexpression of histone methyltransferase EZH2 in cancer. Science 322 1695-1699.

Visone R, Russo L, Pallante P, De Martino I, Ferraro A, Leone V, Borbone E, Petrocca F, Alder H, Croce CM et al. 2007a MicroRNAs (miR)-221 and miR-222, both overexpressed in human thyroid papillary carcinomas, regulate $\mathrm{p} 27 \mathrm{Kip} 1$ protein levels and cell cycle. Endocrine-Related Cancer 14 791-798.

Visone R, Pallante P, Vecchione A, Cirombella R, Ferracin M, Ferraro A, Volinia S, Coluzzi S, Leone V, Borbone E et al. $2007 b$ Specific microRNAs are downregulated in human thyroid anaplastic carcinomas. Oncogene $\mathbf{2 6}$ 7590-7595.

Volinia S, Calin GA, Liu CG, Ambs S, Cimmino A, Petrocca F, Visone R, Iorio M, Roldo C, Ferracin M et al. 2006 A microRNA expression signature of human solid tumors defines cancer gene targets. PNAS $\mathbf{1 0 3}$ 2257-2261.

Voorhoeve PM, le Sage C, Schrier M, Gillis AJ, Stoop H, Nagel R, Liu YP, van Duijse J, Drost J, Griekspoor A et al. 2006 A genetic screen implicates miRNA-372 and miRNA-373 as oncogenes in testicular germ cell tumors. Cell 124 1169-1181.

Wang W, Mouneimne G, Sidani M, Wyckoff J, Chen X, Makris A, Goswami S, Bresnick AR \& Condeelis JS 2006 The activity status of cofilin is directly related to invasion, intravasation, and metastasis of mammary tumors. Journal of Cell Biology 173 395-404.

Weber F, Teresi RE, Broelsch CE, Frilling A \& Eng C 2006 A limited set of human microRNA is deregulated in follicular thyroid carcinoma. Journal of Clinical Endocrinology and Metabolism 91 3584-3591.

Webster RJ, Giles KM, Price KJ, Zhang PM, Mattick JS \& Leedman PJ 2009 Regulation of epidermal growth factor receptor signaling in human cancer cells by microRNA-7. Journal of Biological Chemistry 284 5731-5741.

Wei JS, Song YK, Durinck S, Chen QR, Cheuk AT, Tsang P, Zhang Q, Thiele CJ, Slack A, Shohet J et al. 2008 The $\mathrm{MYCN}$ oncogene is a direct target of miR-34a. Oncogene 27 5204-5213.

Welch C, Chen Y \& Stallings RL 2007 MicroRNA-34a functions as a potential tumor suppressor by inducing apoptosis in neuroblastoma cells. Oncogene $\mathbf{2 6}$ 5017-5022.

Wolf K, Mazo I, Leung H, Engelke K, von Andrian UH, Deryugina EI, Strongin AY, Bröcker EB \& Friedl P 2003 Compensation mechanism in tumor cell migration: mesenchymal-amoeboid transition after blocking of pericellular proteolysis. Journal of Cell Biology 160 267-277.

Wong CW, Lee A, Shientag L, Yu J, Dong Y, Kao G, Al-Mehdi AB, Bernhard EJ \& Muschel RJ 2001 Apoptosis: an early event in metastatic inefficiency. Cancer Research 61 333-338.

Woods K, Thomson JM \& Hammond SM 2007 Direct regulation of an oncogenic micro-RNA cluster by E2F transcription factors. Journal of Biological Chemistry $\mathbf{2 8 2}$ 2130-2134.

Wu MY \& Hill CS 2009 Tgf-beta superfamily signaling in embryonic development and homeostasis. Developmental Cell 16 329-343.

Würdinger T, Tannous BA, Saydam O, Skog J, Grau S, Soutschek J, Weissleder R, Breakefield XO \& Krichevsky AM 2008 miR-296 regulates growth factor receptor overexpression in angiogenic endothelial cells. Cancer Cell 14 382-393.

Yamamichi N, Shimomura R, Inada K, Sakurai K, Haraguchi T, Ozaki Y, Fujita S, Mizutani T, Furukawa C, Fujishiro M et al. 2009 Locked nucleic acid in situ hybridization analysis of miR-21 expression during colorectal cancer development. Clinical Cancer Research 15 4009-4016.

Yang WJ, Yang DD, Na S, Sandusky GE, Zhang Q \& Zhao G 2005 Dicer is required for embryonic angiogenesis during mouse development. Journal of Biological Chemistry $\mathbf{2 8 0}$ 9330-9335.

Yang H, Kong W, He L, Zhao JJ, O'Donnell JD, Wang J, Wenham RM, Coppola D, Kruk PA, Nicosia SV et al. 2008 MicroRNA expression profiling in human ovarian cancer: miR-214 induces cell survival and cisplatin resistance by targeting PTEN. Cancer Research $\mathbf{6 8}$ 425-433.

Zhang L, Huang J, Yang N, Greshock J, Megraw MS, Giannakakis A, Liang S, Naylor TL, Barchetti A, Ward MR et al. 2006 microRNAs exhibit high frequency genomic alterations in human cancer. PNAS $\mathbf{1 0 3}$ 9136-9141.

Zhang L, Volinia S, Bonome T, Calin GA, Greshock J, Yang N, Liu CG, Giannakakis A, Alexiou P, Hasegawa K et al. 2008 Genomic and epigenetic alterations deregulate microRNA expression in human epithelial ovarian cancer. PNAS 105 7004-7009.

Zhang Y, Guo J, Li D, Xiao B, Miao Y, Jiang Z \& Zhuo H 2009 Down-regulation of miR-31 expression in gastric cancer tissues and its clinical significance. Medical Oncology [in press].

Zhao L, Samuels T, Winckler S, Korgaonkar C, Tompkins V, Horne MC \& Quelle DE 2003 Cyclin $\mathrm{G}_{1}$ has growth inhibitory activity linked to the ARF-Mdm2-p53 and pRb tumor suppressor pathways. Molecular Cancer Research 1 195-206.

Zhu S, Wu H, Wu F, Nie D, Sheng S \& Mo YY 2008 MicroRNA-21 targets tumor suppressor genes in invasion and metastasis. Cell Research 18 350-359. 